\title{
Command Responsibility in the Times of Tokhang: Defining Military-likeness under Article 28(a) of the Rome Statute
}

\author{
Raphael Lorenzo A. PANGALANGAN* \\ Jindal Global Law School, O.P. Jindal Global University, Sonipat, India \\ Corresponding author: Raphael Lorenzo A. PANGALANGAN, Email: rlap2@cantab.ac.uk
}

(Received 2 December 2020; revised 7 November 2021; accepted 22 November 2021;

first published online 8 February 2022)

\begin{abstract}
President Rodrigo Duterte won on a law-and-order campaign promise to fatten the fish in Manila Bay with the corpses of criminals. By the time the Philippines withdrew from the Rome Statute, the body count stood at a reported 30,000, a fifth of whom were openly killed in Philippine National Police (PNP) anti-drug operations. Duterte has since been accused of Crimes Against Humanity, inter alia, as "a person effectively acting as a military commander" under Article 28(a) of the Rome Statute for failing to prevent, repress, and report the crimes of his police subordinates. This study tests the veracity of that claim. It seeks to determine whether Duterte, as the Chief Executive and overall superior of the PNP - statutorily, a civilian group - may be held liable as a military-like commander under the doctrine of command responsibility. At the core of this query lies a singular concern far from simple: the meaning of military-likeness.
\end{abstract}

Keywords: Drug War; Police Violence; Command Responsibility; Rome Statute; Individual Criminal Liability

"The common sense of mankind demands that law shall not stop with the punishment of petty crimes by little people. It must also reach men who possess themselves of great power[.]"

Robert H. Jackson ${ }^{1}$

Command responsibility, while entrenched in law, continues to be refined. The Rome Statute of the International Criminal Court (ICC), for the first time in the long history of the doctrine, explicitly bifurcates the application of command responsibility between

\footnotetext{
* The author is an Assistant Professor at and Associate Dean of Jindal Global Law School, O.P. Jindal Global University, India. Opinions expressed are solely his own and do not express the views or opinions of his employer.

The author wishes to thank his dissertation supervisor, Carolyn Patty Blum, whose invaluable guidance continues to help shape law studies and life choices alike. He also publishes this piece in memory of Rob Cryer, with whom the author found a professor, a mentor, and a friend.

${ }^{1}$ Robert H. JACKSON, “Opening Statement before the International Military Tribunal” (21 November 1945), online: Robert H Jackson <https://www.roberthjackson.org/speech-and-writing/opening-statement-before-theinternational-military-tribunal/>.
}

(c) The Author(s), 2022. Published by Cambridge University Press on behalf of the Asian Society of International Law. This is an Open Access article, distributed under the terms of the Creative Commons Attribution licence (https://creativecommons.org/ licenses/by/4.0/), which permits unrestricted re-use, distribution, and reproduction in any medium, provided the original work is properly cited. 
two categories: first, under Article 28(a), the military commander or "person effectively acting as a military commander" ("military-like commander"), ${ }^{2}$ and second, under Article 28(b), "civilians occupying de jure and de facto positions of authority" ("civilian superiors"). ${ }^{3}$ While each category comes with its respective elements, Article 28(a) contains more onerous elements in respect of the accused than Article 28(b) in terms of actus reus and mens rea. ${ }^{4}$

The Rome Statute deviates drastically from the doctrine's earlier iterations. Command responsibility finds its roots in the state obligation to "responsibly command" 5 armed troops under International Humanitarian Law $(\mathrm{IHL})^{6}$. Its modern conception as a mode of individual criminal liability was first applied by the United States Military Commission as part of the Law of Armed Conflict in the Trial of Tomoyuki Yamashita who was the Commanding General of the $14^{\text {th }}$ Army Group of the Japanese Army in the Second World War. ${ }^{7}$ Despite the absence of any express finding that Yamashita knew of the crimes of his subordinates, ${ }^{8}$ he was held to a strict liability standard and was found criminally responsible for having:

unlawfully disregarded and failed to discharge his duty as commander to control the operations of the members of his command, permitting them to commit brutal atrocities and other high crimes against people of the United States and of its allies and dependencies, particularly the Philippines. ${ }^{9}$

The strict liability approach, though upheld by the Philippine and American Supreme Courts in Yamashita's Habeas Corpus petitions, ${ }^{10}$ would ultimately be rejected in international law. ${ }^{11}$ The International Criminal Tribunal of Rwanda (ICTR) and the International Criminal Tribunal for the Former Yugoslavia (ICTY) evade Yamashita's shadow by incorporating a mens rea element in their respective command responsibility provisions. ${ }^{12}$ A superior may therefore incur command responsibility for failing to control his subordinates only if he or she "knew or had reason to know" of their criminal conduct. ${ }^{13}$ The ICTR and ICTY likewise

\footnotetext{
${ }^{2}$ The article will refer to military and military-like commanders together as "military(-like)".

${ }^{3}$ Rome Statute of the International Criminal Court, 17 July 1998, 2187 U.N.T.S. 90 (entered into force 1 July 2002) [Rome Statute], art. 28. See Gideon BOAS, James L BISCHOFF and Natalie L REID, Forms of Responsibility in International Criminal Law (Cambridge: Cambridge University Press, 2007) at 254.

${ }^{4}$ Greg R. VETTER, "Command Responsibility of Non-Military Superiors in the International Criminal Court (ICC)" (2000) 25 Yale Journal of International Law 89 at 94. See also Part 3(A)(2).

${ }^{5}$ Hague Convention (IV) Respecting the Laws and Customs of War on Land and Its Annex: Regulations Concerning the Laws and Customs of War on Land, 18 October 1907 (entered into force 26 January 1910), online: RefWorld <https:// www.refworld.org/docid/4374cae64.html>, art. 1.

${ }^{6}$ In re Yamashita, 327 US 1, [1946] (Murphy, J., dissenting) at 37. See James D. LEVINE, "The Doctrine of Command Responsibility and Its Application to Superior Civilian Leadership: Does the International Criminal Court Have the Correct Standard" (2007) 193 Milwaukee Law Review 52 at 80.

${ }^{7}$ Yamashita v. Styer (G.R. No L-129), [1945] 75 SCRA 563 at 570 [Yamashita v. Styer].

${ }^{8}$ In re Yamashita, supra note 6 at 50 (Rutledge, J., dissenting).

${ }^{9}$ United States Military Commission, "Trial of General Tomoyuki Yamashita (Judgment of the United States Military Commission, Manila, 4 February 1946)" in Law Reports of Trial of War Criminals (United Nations War Crimes Commission 1948) at 28.

${ }^{10}$ Ibid; Yamashita v. Styer, supra note 7.

${ }^{11}$ The Prosecutor v. Jean-Pierre Bemba Gombo, Decision of 15 June 2009, Pre-Trial Chamber II, Case No. ICC-01/ 05-01/08 at para. 351 [Bemba].

12 Prosecutor v. Zdravko Mucic aka "Pavo", Hazim Delic, Esad Landzo aka "Zenga", Zejnil Delalic, Judgement of 20 February 2001, Appeals Chamber, Case No. IT-96-21-A at paras. 189-198 [Delalić].

${ }^{13}$ Statute of the International Criminal Tribunal for Rwanda (as last amended on 13 October 2006), UN Security Council (1994), art. 6(3); Statute of the International Criminal Tribunal for the Former Yugoslavia (as amended on 17 May 2002), UN Security Council (1993), art. 7(3).
} 
applied command responsibility to civilian and military superiors alike, ${ }^{14}$ whether de jure or de facto, ${ }^{15}$ within or without the theatre of war. ${ }^{16}$

The unitary application of command responsibility to both military and civil leaders was made without much controversy in light of the ad hoc tribunals' respective charter's use of the term "superior" - a fluid concept which encompasses both civilian and military authority. ${ }^{17}$ So long as a "superior has effective control over subordinates", then the same rule of responsibility would apply. ${ }^{18}$ What began as a state obligation to responsibly command military armies has thus since developed to "reach areas outside of armed conflicts and outside of traditional armed forces." ${ }^{19}$

The Rome Statute only partially resembles the ad hoc tribunals' approach. Similarly, the Statute does not limit command responsibility to military actors or contexts. However, rather than adjudging all superiors against the same legal standard, the Statute hinges the applicable rule on the character of the accused's authority: military, military-like, or civilian. While either end of the civilian-military spectrum has been defined in large part, ${ }^{20}$ the same cannot be said for the amorphous middle ground. Indeed, the category of "military-like" commanders was precisely created to address new challenges encountered by old doctrines within the grey in-betweens of the civilian and military domains. ${ }^{21}$

Neither the Rome Statute nor ICC jurisprudence provide much guidance on the metes-and-bounds of the hybrid category. In Prosecutor $v$ Bemba, ("Bemba" or "PTC II Decision"), the military-like category was interpreted early-on by the Pre-Trial Chamber II (PTC II) to embrace those superiors "not elected by law to carry out a military commander's role" yet "perform it de facto by exercising effective control over a group of persons through a chain of command." ${ }^{22}$ It encompasses superiors of "government forces such as

\footnotetext{
${ }^{14}$ Prosecutor v. Radovan Karadžić, Judgement of 24 March 2016, Trial Chamber, Case No. IT-95-5/18-T at para. 58 [Karadžić].

${ }^{15}$ Juvénal Kajelijeli v. The Prosecutor, Judgement of 23 May 2005, Appeals Chamber, Case No. ICTR-98-44A-A23 at para. 85.

${ }^{16}$ Guénaël METTRAUX, The Law of Command Responsibility (Oxford: Oxford University Press, 2009) at 97; Jamie A. WILLIAMSON, "Command Responsibility in the Case Law of the International Criminal Tribunal for Rwanda" (2002) 13 Criminal Law Forum 365 at 366.

${ }^{17}$ Michael J. SHERMAN, “Standards in Command Responsibility Prosecutions: How Strict, and Why” (2018) 38 The Northern Illinois Law Review 298 at 318.

${ }^{18}$ Delalić, supra note 12 at para. 192; The Prosecutor v. Ignace Bagilishema, Judgement of 3 July 2002, Appeals Chamber, Case No. ICTR-95-1A-A at para. 50.

${ }^{19}$ See generally Patrick WALSH and Joshua F. BERRY, "Expanding Command Responsibility beyond War: The Application of the Doctrine of Command Responsibility to Human Rights Law" (2016) 11 Liberty University Law Review 423.

${ }^{20}$ See Bemba, supra note 11 at para. 78 and 408: “...the civilian population [...] comprises all persons who are civilians as opposed to members of armed forces and other legitimate combatants' [...] [T] he term 'military commander' refers to a category of persons who are formally or legally appointed to carry out a military commanding function (i.e. de jure commanders)".

${ }^{21}$ Committee of the Whole Summary Record of the $1^{\text {st }}$ Meeting, held on 16 June 1998, UN Doc. A/CONF.183/C.1/SR.1 (1998) [Summary Record], at 82: "[A] point that must be addressed [...] [is] a situation in which civilians were effectively part of a command structure that involved military or paramilitary forces. The question did not concern a straightforward civilian bureaucracy, but civilians at a high level who were in fact engaged in the command or control of lethal forces. It was important that, in providing for the responsibility of superiors, the drafters of the statute should not omit the possibility of dealing with such persons."

${ }^{22}$ Bemba, supra note 11 at para. 409 citing The Prosecutor v. Tihomir Blaškić, Judgement of 3 March 2000, Trial Chamber, Case No. IT-95-14-T at para. 300; Prosecutor v. Zlatko Aleksovski, Judgement of 25 June 1999, Trial Chamber, Case No. IT-95-14/1-T [Aleksovski], at para. 76; The Prosecutor v. Sylvestre Gacumbitsi, Judgement of 7 July 2006, Appeals Chamber, Case No. ICTR-2001-64-A, at para. 143; Juvénal Kajelijeli v. The Prosecutor, Judgement of 23 May 2005, Appeals Chamber, Case No. ICTR-98-44A-A at para. 85; cf. Prosecutor v. Bemba, Decision of 8 June 2018, Appeals Chamber, Case No. ICC-01/05-01/08 A [Bemba Appeals Judgement]. While the accused was ultimately acquitted by the Appeals Chamber for the failure to establish guilt beyond reasonable
} 
armed police units or irregular (non-government forces), such as rebel groups, paramilitary units including, inter alia, armed resistance movements and militias that follow a structure of military hierarchy or a chain of command". ${ }^{23}$

This enumeration in Bemba reflects the ad hoc tribunal's orthodox understanding of the "de facto military commander" in all instances but one: the "armed police unit". Jurisprudentially, the de facto military commander is defined forthrightly as a superior who, without colour of law, commands a state or non-state armed force. ${ }^{24}$ The crux of that analysis is the existence of the accused's authority over a military force, rather than the subordinate unit's de facto military nature. While civilian and military superiors would be distinguished, ${ }^{25}$ de jure and de facto armies were conflated. ${ }^{26}$ So long as the subordinate group constitutes an "armed group" as defined under $\mathrm{IHL},{ }^{27}$ then its superior would be characterized as a de jure or de facto military commander. Yet, by throwing armed police units into the mix - generally speaking, a civilian group ${ }^{28}$ - the ICC broadens its enquiry beyond the existence of a de facto authority over a military force to include the subordinate group's de facto military nature. Therefore, it would not suffice to determine whether an "armed police unit" constitutes an "armed group" under IHL - which a police unit, unless incorporated into the military, is not. ${ }^{29}$ The ICC opens the floodgates to an additional consideration: a "military-like" character.

Granted, Jean-Pierre Bemba Gombo ("Mr. Bemba") would be ultimately acquitted by the Appeals Chamber (AC) because "one of the elements of command responsibility under article 28(a) of the Rome Statute was not properly established," 30 the AC's evidentiary finding did not in any way undo the doctrinal determination of the PTC II preceding it. The AC's judgement, after all, is an Article 81 appeal against the Trial Chamber Judgement of 21 March 2016, ${ }^{31}$ and not an Article 82 appeal to the 2009 PTC II Decision. ${ }^{32}$

Since the Bemba PTC II Decision remains intact, the question thus arises: what bestows an "armed police unit" military-likeness? The answer to this query is found in the application of the command responsibility doctrine, once again, on the shores of the Philippine islands.

doubt, the Pre-Trial Chamber's doctrinal pronouncement in Bemba continues to have relevance and application to the present research.

${ }^{23}$ Bemba, supra note 11 at para. 410.

${ }^{24}$ Prosecutor v. Zdravko Mucic aka "Pavo", Hazim Delic, Esad Landzo aka "Zenga”, Zejnil Delalic, Judgement of 16 November 1998, Trial Chamber, Case No. IT-96-21-T at para. 354.

${ }^{25}$ Prosecutor v. Dario Kordić, Mario Čerkez, Judgement of 26 February 2001, Trial Chamber, Case No. IT-95-14/2-T, at para. 930 .

${ }^{26}$ See for example Prosecutor $v$ Mladen Naletilićaka 'Tuta' and Vinko Martinović aka 'Štela', Judgment of 31 March 2003, Trial Chamber, Case No. IT-98-34-T, at para. 101 [Martinović].

${ }^{27}$ Prosecutor v. Issa Hassan Sesay, Morris Kallon and Augustine Gbao (the RUF accused), Judgement of 2 March 2009, Case No. SCSL-04-15-T [Sesay], at para. 87. See International Committee of the Red Cross, "Rule 4. Definition of Armed Forces" in International Committee of the Red Cross, International Committee of the Red Cross Customary International Humanitarian Law Database (2005) online: International Committee of the Red Cross Customary IHL Database <https://ihl-databases.icrc.org/customary-ihl/eng/docs/v1_rul_rule4>; cf. Claudia HOFMANN and Ulrich SCHNECKNER, "Engaging Non-State Armed Actors in State and Peace-building: Options and Strategies" (2011) 93 International Law Review of the Red Cross 603.

${ }^{28}$ Sesay, supra note 27 at paras. 87-88.

${ }^{29}$ Prosecutor v. Germain Katanga and Mathieu Ngudjolo Chui, Decision on Confirmation of Charges of 30 September 2008, Pre-Trial Chamber I, Case No. ICC-01/04-01/07 at para. 399.

${ }^{30}$ Bemba Appeals Judgement, supra note 22 at para. 194.

${ }^{31}$ Rome Statute, supra note 3, art. 81.

${ }^{32}$ Rome Statute, supra note 3, art. 82. See also Decision on the Prosecutor's Application for Leave to Appeal the "Decision Pursuant to Article 61(7)(a) and (b) of the Rome Statute on the Charges of the Prosecutor Against Jean-Pierre Bemba Gombo", Decision of 18 September 2009, Pre-Trial Chamber II, Case No. ICC-01/05-01/08-532, at para. 12. 
The Office of the Prosecutor (OTP) of the ICC, on 14 June 2021, filed an Article 15(3) request before the Pre-Trial Chamber I (PTC I) for authorization to investigate the Situation in the Republic of the Philippines ("Situation in the Philippines"). ${ }^{33}$ Come 15 September 2021, the PTC I confirmed there was a reasonable basis to believe that the Crime Against Humanity (CAH) of Murder inter alia was committed in the context of Rodrigo Duterte's "war on drugs" campaign. ${ }^{34}$

Duterte was elected as Philippine President on a law-and-order campaign promise to "fatten the fish in Manila Bay" with the corpses of criminals. ${ }^{35}$ On 1 July 2016 - within 24 hours of his Presidential term - his newly appointed Philippine National Police (PNP) Chief, General Ronald dela Rosa, signed Command Memorandum Circular (CMC) No. 16-2016 launching "Project Double Barrel", the "Anti-Illegal Drugs Campaign Plan". ${ }^{36}$ Enforcing Duterte's campaign promise to eradicate a purported drug epidemic in the Philippines, the PNP pledged to render assistance to the Philippine Drug Enforcement Agency (PDEA) ${ }^{37}$ through two prongs: (i) the Oplan HVT ("Upper Barrel Approach"), which was aimed at high-value targets, and (ii) the Oplan Tokhang ("Lower Barrel Approach"), which was aimed at street-level personalities. ${ }^{38}$ Tokhang is a portmanteau of the words toktok (knock) and hangyo (plead); ${ }^{39}$ referring to the house visits conducted by the PNP to "urge" the surrender of "drug personalities" 40 - the term of art for street drug peddlers and users in Duterte's so called "war on drugs" 41 or "drug war".

Though Project Double Barrel contemplates a two-tiered approach, the PNP has targeted mostly underprivileged communities through the Oplan Tokhang. ${ }^{42}$ Three years into Duterte's term, the body count stood at an estimated $30,000,{ }^{43}$ most of them smalltime drug peddlers and slum-dwelling users, and at least a fifth of them openly killed in

\footnotetext{
33 Office of the Prosecutor, "Public redacted version of "Request for authorization of an investigation pursuant to article 15(3)", 24 May 2021, ICC-01/21-7-SECRET-Exp", ICC-01/21 (14 June 2021) at para. 2 [Request for Authorization].

${ }^{34}$ Decision on the Prosecutor's request for authorization of an investigation pursuant to Article 15(3) of the Statute, Decision of 15 September 2021, Pre-Trial Chamber I, Case No. ICC-01/21, at para. 113 [PTC I Decision].

35 “The president of the Philippines boasts about personally killing drug suspects" The Economist (15 December 2016), online: The Economist <https://www.economist.com/asia/2016/12/15/the-president-of-the-philippinesboasts-about-personally-killing-drug-suspects>.

${ }^{36}$ Philippine National Police, "Command Memorandum Circular No 16-2016: PNP Anti-Illegal Drugs Campaign Plan - 'Project 'Double Barrel”' (1 July 2016), online: Directorate for Investigation and Detective Management <https://didm.pnp.gov.ph/images/Command\%20Memorandum\%20Circulars/CMC\%202016-16\%20PNP\%20ANTIILLEGAL\%20DRUGS\%20CAMPAIGN\%20PLAN\%20\%20PROJECT\%20DOUBLE\%20BARREL.pdf> [CMC 16-2016].

${ }^{37}$ See Republic Act No. 9165, "Comprehensive Dangerous Drugs Act of 2002" (2002), online: Philippine Drug Enforcement Agency <https://pdea.gov.ph/images/Laws/RA9165.pdf> at section 82. The PDEA is the Office of the President's implementing arm for the enforcement of RA 9165.

${ }^{38}$ Bea CUPIN, “Warning to drug dealers: PNP has 'double barrel' plan” Rappler (29 June 2016), online: Rappler $<$ https://www.rappler.com/nation/dela-rosa-pnp-plan-drugs>.

39 Rise Up for Life and for Rights et al., "Communication and Complaint in re. the Situation in the Philippines" (27 August 2018) at 2 [Communication].

${ }^{40}$ CMC 16-2016, supra note 36 at 1.

${ }^{41}$ Ibid; $c f$. Gabriel Pabico LALU, “Int'l local professors validate 5,000 deaths in PH due to war on drugs" Inquirer (25 June 2018), online: Inquirer <https://newsinfo.inquirer.net/1003944/intl-local-professors-verify-5000-deathsin-ph-due-to-drug-war>.

${ }^{42} \mathrm{Ibid}$.

${ }^{43}$ PTC I Decision, supra note 34 at para. 67; Request for Authorization, supra note 33 at 19. See also Rambo TALABONG, “Unreal numbers: Around 2,000 drug war deaths missing in Duterte gov't tally" Rappler (11 September 2020), online: Rappler <www.rappler.com/nation/missing-drug-war-deaths-duterte-governmenttally>; Emmanuel TUPAS, “29,000 deaths probed since drug war launched” Philippine Star (6 March 2019), online: Philippine Star <https://www.philstar.com/nation/2019/03/06/1898959/29000-deaths-probed-drug-war-launched>.
} 
police operations. ${ }^{44}$ The Oplan Tokhang has thus become synonymous with the extrajudicial killings in the war on drugs and, critics allege, gives rise to Duterte's own liability as a military-like commander. ${ }^{45}$ This study tests the veracity of this claim.

The article will determine whether Duterte, as Chief Executive and overall superior of the PNP, may be held liable as a "person effectively acting as a military commander" under Article 28(a) of the Rome Statute. ${ }^{46}$ Part I explores the civilian-military gap to define the "military-like group". This part will identify the defining characteristic which, when adopted by the PNP - statutorily, a civilian police force ${ }^{47}$ - gives it militarylikeness. Part II will then establish the elements of Article 28(a) within the Philippine context, namely: (i) the superior-subordinate relationship between the President and the PNP; (ii) the mens rea element ${ }^{48}$ of knowledge; and (iii) the actus reus, ${ }^{49}$ the failure to take all necessary and reasonable measures to prevent, repress, or report the PNP's criminal conduct. Among the many ways omission may be criminal, Part III draws the fine nuances among and between the modes of omission liability under the Rome Statute through the principle of fair labelling..$^{50}$ This part will address how Article 28(a), in contrast to Articles 25(c) and 28(b), best captures Duterte's criminal culpability for failing to prevent, repress, and punish Crimes Against Humanity committed in his war on drugs.

\section{The Military-Mind: Separating Civilian and Military Spaces}

\section{A. Defining Military-likeness}

What confers "armed police units" military-likeness? Nora Karsten explores four possibilities: (i) the mandate to use lethal force; (ii) the command structure of the entity; (iii) the nature and scope of the superior's authority; and (iv) the entity's "deployability" ${ }^{51}$ Each test is briefly surveyed:

(i) Considering that Bemba requires that the police units be armed, weaponry is an obvious candidate for militarization. Upon closer scrutiny, however, militaria serves as an indeterminate standard considering that "all kinds of items may be turned into

\footnotetext{
${ }^{44}$ Office of the Prosecutor of the International Criminal Court, "Report on Preliminary Examination Activities 2018" (5 December 2018), at 51-53; Michael Joe DELIZO, “Over 6,000 killed in nearly 3 years of PH drug war: PNP” ABS-CBN News (18 June 2019), online: ABS-CBN News <https://news.abs-cbn.com/news/06/18/19/over-6000killed-in-nearly-3-years-of-ph-drug-war-pnp> [Report on Preliminary Examination Activities 2018].

${ }^{45}$ Rie TAKUMI, "Poor communities most vulnerable in gov't war on drugs - research" GMA News (25 June 2018), online: GMA News <https://www.gmanetwork.com/news/news/nation/658104/poor-communities-mostvulnerable-in-gov-t-war-on-drugs-research/story/>.

${ }^{46}$ Rome Statute, supra note 3, art. 127; cf. Pangilinan v. Cayetano (Petition), G.R. No. 238875 (2018); see generally Ryan Hartzell Carino BALISACAN, "Was President Duterte's Unilateral Withdrawal of the Philippines from the Rome Statute Legally Valid?”, Cambridge International Law Journal Blog (21 June 2018), online: Cambridge International Law Journal Blog <www.cilj.co.uk/2018/06/21/was-president-dutertes-unilateral-withdrawal-ofthe-philippines-from-the-rome-statute-legally-valid/>; Raphael Lorenzo A. PANGALANGAN, "VFA Withdrawal and the Faults of Philippine Formalism" (2021) 93 Philippine Law Journal 709.

${ }^{47}$ Republic Act No 6975, “An Act Establishing the Philippine National Police under a Reorganized Department of the Interior and Local Government and for Other Purposes" (1990) as amended by Republic Acts Nos. 8551 and 9708 ("RA 6975") at section 2.

${ }^{48}$ Mettraux, supra note 16 at 30.

${ }^{49}$ Bing Bing JIA, “The Doctrine of Command Responsibility: Current Problems" (2000) 3 Yearbook of International Humanitarian Law 131 at 141.

${ }^{50}$ Douglas GUILFOYLE, "Responsibility for Collective Atrocities: Fair Labelling and Approaches to Commission in International Criminal Law" (2011) 64 Current Legal Problems 255 at 260: "[t]he fair labelling principle aims to ensure that the label describing criminal conduct accurately reflects its wrongfulness and its severity."

${ }^{51}$ See Nora KARSTEN, "Distinguishing Military and Non-military Superiors: Reflections on the Bemba Case at the ICC' (2009) 7(5) Journal of International Criminal Justice 983.
} 
weapons." 52 Indeed, as the Rwandan atrocities illustrate, grave crimes may be executed through machine guns and machetes alike. ${ }^{53}$ Street gangs, mafias, and police forces do not morph into military(-like) armies with a pull of the trigger much in the same way that soldiers are not transformed into civilians by choosing fisticuffs over firearms.

(ii) Bemba points to a formational standard by considering those groups, which "follow a structure of military hierarchy or a chain of command", ${ }^{54}$ as military-like. But like the militaria threshold, neither does a group's structure dictate its character, as civilian units do formally adopt, but are not necessarily militarized by, military-styled structures. ${ }^{55}$ It is not "untypical that irregular armed groups, for various reasons, deviate from the structure of a conventional army". ${ }^{56}$ On the other hand, neither the Solicitor General $^{57}$ nor the Police General (i.e. the Chief of Police) ${ }^{58}$ become military officers by title alone.

(iii) The Rome Statute bifurcates the application of command responsibility in recognition of the differences in the "nature and scope of authority" between civilian and military relations. While military relations embody a "penal dimension", there is "no comparable punishment system for civilians". ${ }^{9}$ Karsten accurately rebuts that, as evidenced by the "duty to report", the power to punish fails to demarcate the civilianmilitary divide. All superiors, military or civilian, incapable of directly punishing their subordinates are obligated "to submit the matter to the competent authorities for investigation and prosecution". ${ }^{60}$ The absence of penal authority does not, therefore, refute its military character.

(iv) Karsten proposes her standard-of-choice: the group's underlying rationale. An armed police unit is "considered a military entity for the purposes of Article 28(a) if its underlying purpose is to act or be deployed as a party to an armed conflict". ${ }^{1}$ Thus, "once the civilian police is militarized, in the sense that its members take part in or are supposed to take part in armed conflict, the underlying purpose converts the police unit into a military entity". Conversely, a non-military group is "an entity which does not share such rationale". ${ }^{2}$

Karsten admirably abandons the facial and formalistic differences between the military and police by drawing a substantive distinction: "deployability". This article takes a differing view for practical, syllogistic, and ontological reasons.

First, the "deployability" test assumes that the sole purpose of a military group is to engage in armed conflict. This approach, however, fails to consider the reality that what is essentially military and non-military deviates from one jurisdiction to the other. Indeed, in the Philippines, military and civilian forces are foisted into a world of blends where the PNP, though statutorily severed from the Armed Forces of the Philippines (AFP), remains rooted in militaristic qualities ${ }^{63}$ inherited from the

\footnotetext{
${ }^{52}$ Ibid., at 1000 .

${ }^{53}$ Georges Anderson Nderubumwe Rutaganda v. The Prosecutor, Judgement of 26 May 2003, Appeals Chamber, Case No. ICTR-96-3-A at 577.

${ }^{54}$ Bemba, supra note 11 at para. 410.

${ }^{55}$ Karsten, supra note 51 at para. 1001.

56 Ibid.

${ }^{57}$ See Republic Act No. 9417, "An Act to Strengthen the Office of the Solicitor General" (2007).

${ }^{58}$ RA 6975, supra note 47, at section 25; cf. Republic Act No. 11200, "An Act Providing for the Rank Classification in the Philippine National Police" (2019) at section 1.

${ }^{59}$ Summary Record, supra note 21 at 67.

${ }^{60}$ Karsten, supra note 51 at 999; cf. Rome Statute, supra note 3, art. 28.

${ }^{61}$ Karsten, supra note 51 at 1002.

62 Ibid., at 1003.

${ }^{63}$ See RA 6975, supra note 47, at sections 6, 20, 23, 25, and 28; cf. Philippine National Police, "Eleven General Orders of a Duty Guard" in Philippine National Police, PNPM-DO-DS-3-13, Philippine National Police Operational Procedures (Philippine National Police December 2013) (“PNPM-DO-DS-3-13").
} 
Philippine Constabulary (PC) - the predecessor military police. ${ }^{64}$ On the other hand, the AFP is empowered to perform traditional police work, such as the enforcement of antidrug activities, ${ }^{65}$ and is unapologetically utilized for civilian services. ${ }^{66}$ The purported bright civilian-military divide is, in reality, not only pliable, but blurred. Police and military functions are not neatly divided with mathematical precision into fields of black and white and do not dependably distinguish the civilian and military domains. ${ }^{67}$

Second, Karsten claims that a police unit's statutorily defined "purpose" determines military-likeness. ${ }^{68}$ The view is a non sequitur and undermines the effect of state-sanction in militarization. Any force, whether labelled "police" or otherwise, that is created by the state to engage in armed conflict is not a mere military-like group, but is part of the military force per se. ${ }^{69}$ It is only absent a legal fiat that a group's status would "be judged on the facts and in light of the criteria for defining armed forces." ${ }^{70}$ But when the purported "civilian" armed police unit is militarized in law, it thereby constitutes an "organized armed force, group, or unit"71 - i.e. a military force.

Third, the deployability theory conflates two distinct principles: ethos (character) ${ }^{72}$ and telos (purpose).$^{73}$ As previously discussed, the application of Article 28 is pre-conditioned on the superior's military, military-like, or civilian character; yet hinging that determination on a subordinate group's underlying purpose attempts to define the military ethos in teleological terms.

The reasoning is misplaced. What affords militaries "special character" separate from civilian life ${ }^{74}$ is not the function in which they engage in, but the values they espouse. ${ }^{75}$ The mark of military character is neither weaponry, structure, nor purpose, but disposition - the "military-mind". ${ }^{76}$ Both police and military units share in the state's "monopoly of force", yet they subscribe to different rules. While the use of force is a measure of "last resort" for the police, ${ }^{77}$ it is not only presumed, but primary in military life. ${ }^{78}$ It is that propensity of bellicose recourse, engrained and epitomized by the military that sets the soldier apart from the civilian. ${ }^{79}$ The martial ethos is thus not defined by the military

\footnotetext{
${ }^{64}$ President of the Philippines, "Executive Order No. 389, series of 1950, Reorganizing the Armed Forces of the Philippines" (23 December 1950).

${ }^{65}$ Integrated Bar of the Philippines v. Zamora, [2000] G.R. No. 141284, 338 SCRA 81 at 117 [Zamora].

${ }^{66}$ Republic Act No. 7898, “AFP Modernization Act” (1995) at section 3.

${ }^{67}$ Samuel E. FINER, The Man on Horseback: The Role of the Military in Politics (New Jersey: Transaction Publishers 2002) at xiv. See also Yaël RONEN, "Superior Responsibility of Civilians for International Crimes Committed in Civilian Settings” (2010) 43 Vanderbilt Journal of Transnational Law 313 at 349.

${ }^{68}$ Karsten, supra note 51 at 1001-1003.

${ }^{69}$ Samuel P. HUNTINGTON, The Soldier and the State: The Theory and Politics of Civil-Military Relations (Massachusetts: Belknap Press 2008) at 11.

${ }^{70}$ Jean-Marie HENCKAERTS and Louise DOSWALD-BECK, Customary International Humanitarian Law - Volume I: Rules (Cambridge: Cambridge University Press 2009) at Rule 4; See Sesay, supra note 27 at 88.

${ }^{71}$ Rule 4. Definition of Armed Forces, supra note 27.

72 Roger CRISP, ed., Nicomachean Ethics (Cambridge: Cambridge University Press 2000) at 23-24.

${ }^{73}$ Michael J. SANDEL, Justice: A Reader (Oxford: Oxford University Press 2007) at 301.

${ }^{74}$ Cudia v. Superintendent of the Philippine Military Academy (G.R. No. 211362), [2015] 751 SCRA 469 at 519.

${ }^{75}$ See Pauline COLLINS, Civil-Military 'Legal' Relations: Where to from Here? (Leiden: Brill 2018) at 8.

${ }^{76}$ Ibid.

77 People v. Ulep (G.R. No. 132547), [2000] 340 SCRA 688, at 700 [Ulep]. See Code of Conduct for Law Enforcement Officials, GA Res. 34/169, UN Doc. A/RES/34/169 (1980), art. 9; Basic Principles on the Use of Force and Firearms by Law Enforcement Officials Adopted by the Eighth United Nations Congress on the Prevention of Crime and the Treatment of Offenders, Havana, Cuba, 27 August to 7 September 1990 (1990) at 3-5.

${ }^{78}$ Gloria GAGGIOLI, ed., Expert Meeting, The Use of Force in Armed Conflicts: Interplay between the Conduct of Hostilities and Law Enforcement Paradigms" (Geneva: International Committee of the Red Cross 2013) at 8.

${ }^{79}$ Collins, supra note 75 at 246; International Committee of the Red Cross, "International Humanitarian Law and the challenges of contemporary armed conflicts" (October 2011), online: International Committee of the Red Cross <http://www.rulac.org/assets/downloads/2011_Contemporary_Challenges_report.pdf>.
} 
operation per se, but by the mind behind the matter - the values of the military man: ${ }^{80}$ authoritarianism and bellicosity. ${ }^{81}$

Military character is defined by neither the use of force nor the purpose to engage in it, but the systematically inculcated disposition to use that force $a b$ initio. The telos of a military group may be to engage in successful armed combat, ${ }^{82}$ but its ethos is the inclination to resort to force to compel compliance. ${ }^{83} \mathrm{An}$ armed police unit is therefore militarized not by wearing the combat helmet, but by donning the proverbial military cap. Karsten is therefore only partially correct. Indeed, military arms, structures, and practices may be indicative of militarization, but "do not as such unequivocally determine the military or civilian status of the unit or the superior" ${ }^{84}$ But neither is it their function. Rather, it is the systematic disavowal of the rules of minimal force that convey to civilian police forces military-likeness.

By abandoning their civilian ethos, the "armed police unit" falls short of its nonmilitary telos and functions as a group akin to the military - i.e. a military-like force. That change in function is no threshold per se, but a product of the essential military characteristic: the military mind.

\section{B. The Creeping Militarization of the Philippine National Police}

From the Philippine Commonwealth era to as recent as 1990, law enforcement was a function of the Philippine Constabulary (PC) - the military police. ${ }^{85}$ Though a "civilian" Integrated National Police (INP) was created under the dictatorship of Ferdinand E. Marcos, the INP remained a component of the PC, was heavily militarized, and was co-opted throughout the martial law era ${ }^{86}$ to use violence as a medium for enforcing civilian control. ${ }^{87}$ It was not until the ratification of the 1987 Constitution that the establishment of "one police force" "civilian in character" was envisaged. ${ }^{88}$ Echoing the Constitution's civilian police model, ${ }^{89}$ Republic Act No. (RA) 6975 was passed on 15 December 1990 creating the PNP. ${ }^{90}$ Overnight, the constabulary responsible for Marcosian atrocities was conferred civilian character. ${ }^{91}$

The Philippines attempted to detach law enforcement from its military past by civilianizing the profession in doctrine. Thirty years later, the police-military divide remains blurred. Rather than having separated civilian and military realms, the PNP-AFP dynamic

\footnotetext{
${ }^{80}$ Huntington, supra note 69 at 60.

${ }^{81}$ Ibid., at 59.

${ }^{82}$ Ibid., at 11.

${ }^{83}$ Ibid. See also Collins, supra note 75 at 245.

${ }^{84}$ Karsten, supra note 51 at 1003.

${ }^{85}$ Carpio v. Executive Secretary (G.R. No. 96409), [1992] 207 SCRA 291 at 293; cf. Commonwealth Act No. 1, "The National Defense Act" (1935); RA 6975, supra note 47.

${ }^{86}$ Republic Act No. 10368, "Human Rights Victims Reparation and Recognition Act of 2013" (2013) at section 2. The "regime of former President Ferdinand E. Marcos covering the period from September 21, 1972 to February 25, 1986" where thousands of Filipinos "were victims of [...] gross human rights violations."

${ }^{87}$ See Cecilia MUÑOZ-PALMA, "Closing remarks of the President of the Constitutional Commission at the final session" Official Gazette (1986), online: Official Gazette <https://www.officialgazette.gov.ph/1986/10/15/closingremarks-of-the-president-of-the-constitutional-commission-at-the-final-session-october-15-1986/>.

${ }^{88}$ Constitution of the Republic of the Philippines (1987), art. XVI, section 6 [1987 Constitution].

${ }^{89}$ See Francis PAKES, Comparative Criminal Justice (New York: Routledge 2015) at 55.

${ }^{90}$ Republic v. Asuncion (G.R. No. L-108208), [1994] 231 SCRA 211 at 222 [Asuncion].

${ }^{91}$ RA 6975, supra note 47 at section 23. See also Manalo v. Sistoza (G.R. No. 107369), [1999] 312 SCRA 239 at 249; Department of Budget and Management v. Manilas Finest Retirees Association (G.R. No. 169466), [2007] 523 SCRA 90 at 100. Cf. Gemmo FERNANDEZ et al., "Marcosian Atrocities: Historical Revisionism and the Legal Constraints on Forgetting” (2018) 19 Asia-Pacific Journal on Human Rights and Law 140.
} 
reflects a quasi-military police model where either roles are not only intertwined but interchangeable. ${ }^{92}$ The AFP, on one hand, has penetrated civilian spaces by working within a realm of "permissible use", such as by providing assistance to the police in anti-drug projects. $^{93}$ On the other hand, the PNP has retained military-like qualities by adopting militaristic command structures and systems ${ }^{94}$ and by sharing in the state's "monopoly of force" with the AFP, albeit presumably tempered by the principle of minimal force ${ }^{95}$ vis-à-vis their military counterpart, which tends to extremes. ${ }^{96}$

What truly "militarizes" the PNP is its abandonment of that presumption. The PNP has fought at the forefront of a drug war responsible for the loss of a reported 30,000 lives, ${ }^{97}$ over 6,000 of whom were openly killed in police operations at the time the Philippines' withdrawal from the Rome Statute became effective ${ }^{98}$ - an average of at least five victims daily. It is not only the PNP's structure but its orientation that supposedly separates it from the $\mathrm{PC},{ }^{99}$ yet it is its internalization of that martial ethos, of the systematically inculcated disposition to use violence that reveals its military-likeness. ${ }^{100}$

Dutertian rule has shown that the civilian-military gap is but legal fiction. Like its Chief Executive, the PNP is relentless; foregoing the rules of civilian life and donning a "shoot first, think later" attitude ${ }^{101}$ reminiscent of the military police that preceded it. Authoritarian bellicosity is thus reflected in two aspects in the war on drugs: (i) intrapersonally, between the superior (i.e. Duterte) and the subordinate force (i.e. the PNP), which dutifully carries out its commander's will; and (ii) inter-personally, between the subordinate force and their prey (i.e. "drug personalities").

It has been said that "[t]he government is good or bad as [the President] is good or bad". ${ }^{102}$ The PNP, as with the entirety of the executive branch, is in its essence chameleonic in how it emulates the character and personality of the sitting President. ${ }^{103}$ Duterte - a self-styled authoritarian ${ }^{104}$ and self-confessed murderer ${ }^{105}$ - lends force to

\footnotetext{
${ }^{92}$ Pakes, supra note 89 at 55-6.

${ }^{93}$ Zamora, supra note 65 at 112; cf. RA 7898, supra note 66 at section 3.

${ }^{94}$ PNPM-DO-DS-3-2-13, supra note 63, Rule 12. Cf. Armed Forces of the Philippines, Code of Ethics (1955), art. II Section 2(3) [Code of Ethics]; RA 6975 supra note 47 at section 28.

${ }^{95}$ Ulep, supra note 77. Cf. PNPM-DO-DS-3-2-13, supra note 63, Rule 24(d) on the "Minimum necessary force principle". on the "protect life" principle, see Report of the Special Rapporteur on Extrajudicial, Summary or Arbitrary Executions, Christof Heyns, UN Doc. A/HRC/26/36 (2014) at 72.

${ }^{96}$ Code of Ethics, supra note 94, art. III, section 2(15). Cf. International Committee of the Red Cross, "Violence and the Use of Force" (Geneva: International Committee of the Red Cross 2015) at 43.

${ }^{97}$ PTC I Decision, supra note 34 at 67; Request for Authorization, supra note 33 at 19; Talabong, supra note 43; Tupas, supra note 43.

${ }_{98}$ Philippine Drug Enforcement Agency, “\#RealNumbersPH Year 4" Facebook Page of Realnumbersph (4 September 2020), online: Facebook Page of Realnumbersph <https://www.facebook.com/realnumbersph/photos/pcb.1720964634751734/1720964458085085>. Cf. Phil ROBERTSON, “Another Spike in Philippines' 'Drug War' Death: Latest Data Shows Police Killings Rising amid Covid-19 Pandemic" Human Rights Watch (28 September 2020), online: Human Rights Watch <https://www.hrw.org/news/2020/09/28/another-spike-philippines-drugwar-deaths>.

${ }^{99}$ Asuncion, supra note 90 at 224.

${ }^{100}$ Huntington, supra note 69 at 60.

${ }^{101}$ People v. Oares, [2018], Crim Case No. C-102925-7, Regional Trial Court Branch 125 at 32 [Oares].

${ }^{102}$ Forbes v. Tiaco (G.R. No. 6157), [1910] 16 SCRA 534646 [Forbes].

${ }^{103}$ Marcos v. Manglapus (G.R. No. 88211), [1989] 177 SCRA 668 at 691; Boac v. Cadapan (G.R. Nos. 184461-184462), [2011] 649 SCRA 618 at 623 [Boac].

${ }^{104}$ Walden BELLO, "Rodrigo Duterte: A Fascist Original" in Nicole CURATO, ed., A Duterte Reader: Critical Essays on Rodrigo Duterte's Early Presidency (New York: Southeast Asia Program Publications 2017) at 77.

${ }^{105}$ Hannah ELLIS-PETERSEN, “Duterte confesses: 'My only sin is the extrajudicial killings”" The Guardian (28 September 2018), online: The Guardian <https://www.theguardian.com/world/2018/sep/28/duterte-confessesmy-only-sin-is-the-extrajudicial-killings>.
} 
that adage. Beholden to the President, the PNP dons the military mind through CMC No. 16-2016. The national police enforces an intended civilian mandate in militaristic terms ruthless and unforgiving, ${ }^{106}$ relentless and sustained. ${ }^{107}$ In so doing, it lifts the veil of legal fiction to reveal the wolf in sheep's clothing: a military-like force.

\section{Elements of Command Responsibility}

Duterte is accused of Crimes Against Humanity in his war on drugs. ${ }^{108}$ The Dutertian defence rebuts that those killed in the drug war fought back (nanlaban) and were, therefore, in "Duterte-speak", "killed in legitimate police operations". ${ }^{109}$ But even assuming that extra-judicial killings ("EJKs") were indeed committed, Duterte claims to have had nothing to do with them. ${ }^{110}$ He never ordered them and, thus, cannot be held liable, for EJKs. ${ }^{111}$

Though an affront to elementary notion of fairness, that claim is technically sound. Other than the President's statements sanctioning the drug war, there is " $[n]$ o evidence [that] shows that Duterte planned or ordered specific extrajudicial killings". ${ }^{112}$ Yet, in that same breath, the view is mistaken. The Dutertian defence assumes that criminal liability is incurred through positive conduct alone. It ignores how the Rome Statute deems a superior's failure to prevent, repress, or punish a subordinate's unlawful conduct criminal. Notably, though the doctrine of command responsibility is rooted in military history, its present-day application is not limited to the battlefield. Indeed, the mode of liability applies to any of the crimes under the Rome Statute, without the need for an armed conflict nexus. ${ }^{113}$ What is of relevance, therefore, is not the reality of conflict, but the relationship of command.

Having established Duterte's command over the PNP as a military-like relationship, this part will identify the elements of Article 28(a) in the war on drugs.

\section{A. Conditio Sine Qua Non: The Superior-Subordinate Relationship}

Article 28 liability is preconditioned on a "relationship of subordination". ${ }^{114}$ The superioraccused may be held liable for failing to exercise the tripartite duties of a commander only if he or she, at the outset, had the capacity to control (rather than merely

\footnotetext{
${ }^{106}$ Daniel BEREHULAK “They Are Slaughtering Us Like Animals” The New York Times (7 December 2016), online: The New York Times <https://www.nytimes.com/interactive/2016/12/07/world/asia/rodrigo-duterte-philippines-drugs-killings.html>.

107 Rodrigo DUTERTE, "State of the Nation Address" Official Gazette (2016), online: Official Gazette <https://mirror.officialgazette.gov.ph/2016/07/25/rodrigo-roa-duterte-first-state-of-the-nation-address-july-25-2016/>.

108 Communication, supra note 39 at 1; Report on Preliminary Examination Activities 2018, supra note 44 at 42-58.

${ }^{109}$ Rambo TALABONG, “Don't believe dead suspects fought back? Look at killed cops, says PNP” Rappler (28 September 2017), online: Rappler <https://www.rappler.com/nation/183634-pnp-sws-nanlaban-survey-lookkilled-cops-war-on-drugs>.

${ }^{110}$ Aaron RECUENO, "Duterte never ordered killing of drug suspects - PNP Chief" Manila Bulletin (29 September 2018), online: Manila Bulletin <https://news.mb.com.ph/2018/09/29/duterte-never-ordered-killingof-drug-suspects-pnp-chief/>.

${ }^{111}$ Allan NAWAL, “Duterte: I didn't order police to kill” Philippine Daily Inquirer (29 December 2016), online: Philippine Daily Inquirer <https://newsinfo.inquirer.net/857490/duterte-i-didnt-order-police-to-kill>.

${ }^{112}$ Human Rights Watch, "License to Kill” Human Rights Watch (March 2017), at 17, online: Human Rights Watch <https://www.hrw.org/sites/default/files/report_pdf/philippines0317_insert.pdf>.

113 Bemba, supra note 11, at para. 407.

114 Delalić, supra note 12 at para. 303.
} 
influence $)^{115}$ the conduct of his subordinate. ${ }^{116}$ The existence of a "superior-subordinate relationship" is thus not solely concerned with the legal authority, but the material ability to exercise effective control. ${ }^{117}$ The former is but prima facie evidence of, and cannot be equated with, the latter. ${ }^{118}$ The highest echelons of command, far-removed from the boots on the ground, may indeed be categorized as "superiors," but may, therefore, only be held liable under command responsibility if they actually exercise effective control over their subordinates. ${ }^{119}$

As Philippine President, Duterte exercises that requisite level of control over the PNP. He wears two hats under the 1987 Constitution: one, as Commander-in-Chief of the AFP, and two, as the Chief Executive in whom executive power is vested. ${ }^{120}$ The PNP, having been removed from the military service, falls within Duterte's Chief Executive powers. ${ }^{121}$

In Philippine constitutional tradition, the President himself is the Executive. ${ }^{122}$ The 1987 Constitution establishes "a single, not plural, executive" by which the President enjoys plenary authority over all executive offices. ${ }^{123}$ His supremacy is codified as the power of control under which the Chief Executive is authorized to modify and nullify the official acts of a subordinate and substitute them with his own judgments. ${ }^{124}$ It affords him the authority to alter the functions of the executive offices, ${ }^{125}$ discipline and remove insubordinate officers, ${ }^{126}$ and to assume directly their functions ${ }^{127}$ - presidential prerogatives that shape both official policies and unspoken dispositions. ${ }^{128}$

That power of control is counterbalanced by the "take care" clause, contained in the same constitutional provision, which mandates the President to "ensure that the laws [of the land] be faithfully executed". ${ }^{129}$ When taken together, the right of control and the duty to take care not only empower, but obligate, the President to command, within

\footnotetext{
${ }^{115}$ Prosecutor v. Momčilo Perišić, Judgement of 6 September 2011, Appeals Chamber, Case No. IT-04-81-T at para. 1777.

${ }^{116}$ Rome Statute, supra note 3, art. 28(a). See The Prosecutor v. Laurent Semanza, Judgement and Sentence of 15 May 2003, Trial Chamber III, Case No. ICTR-97-20-T at para. 402; The Prosecutor v. Dragoljub Kunarac, Radomir Kovač and Zoran Vuković, Judgement of 22 February 2001, Trial Chamber II, Case No. IT-96-23-T \& IT-96-23/1-T at para. 396; Prosecutor V. Ildéphonse Nizeyimana, Judgement of 29 September 2014, Appeals Chamber, Case No. ICTR-00-55C-A at 342.

${ }^{117}$ Karadžić, supra note 14 at para. 580. See Pacifico AGABIN, "Accountability of the President under the Command Responsibility Doctrine” (2008) 82 Philippine Law Journal 29 at 31.

${ }_{118}$ Aleksovski, supra note 22 at para. 76.

${ }^{119}$ See Bemba, supra note 11 at para. 417; Karadžić, supra note 14 at para. 581; The Prosecutor v. Prlić et al, Judgement of 29 May 2013 [Prlić], Trial Chamber III, Case No. IT-04-74-T at para. 244. See Otto TRIFFTERER, "Article 28: Responsibility of commanders and other superiors" in Otto TRIFFTERER and Kai AMBOS, eds., Commentary on the Rome Statute of the International Criminal Court (England: Hart 2016) at 1093-1094.

${ }^{120} 1987$ Constitution, supra note 88, art. VII, section 1; Kulayan v. Tan (G.R. No. 187298), [2012] 675 SCRA 483 at 491.

${ }^{121}$ Ibid., art. VII, section 17. Cf. Record of the Constitutional Commission, Vol. 5 (1 October 1986) at 296.

${ }^{122}$ Villena v. Secretary of the Interior (G.R. No. L-46570), [1939] 67 SCRA 451 at 464.

123 Ibid.

${ }^{124}$ Executive Order 292, series of 1987, “Administrative Code of the Philippines” Book III, Title I, Chapter I at section 1 [Executive Order 292]. See Southern Cross Cement Corporation v. Cement Manufacturers Association of the Philippines (G.R. No. 158540), [2005] 465 SCRA 532 at 651; Florin T. HILBAY, Unplugging the Constitution (Quezon City: University of the Philippine Press 2010) at 53.

${ }^{125}$ Biraogo v. The Philippine Truth Commission of 2010 (G.R. No. 192935), [2010] 637 SCRA 78 at 155 [Biraogo]; Mondano v. Silvosa (G.R. No. L-7708), [1955] 97 SCRA 144 at 148.

${ }^{126}$ Noblejas v. Teehankee (G.R. No. L-28790), [1968] 23 SCRA 405 at 408. See RA 6975, supra note 47, at section 42. Cf. Executive Order No. 292, Book IV, Title VIII, Subtitle II, Chapter XI.

${ }^{127}$ Biraogo, supra note 125 at 160; Metropolitan Manila Development Authority v. Concerned Residents of Manila Bay (G.R. Nos. 171947-171948), [2011] 643 SCRA 90 at 135.

${ }^{128}$ Forbes, supra note 102 at 645.

1291987 Constitution, supra note 88, art. VII, section 17.
} 
legally imposed limits, ${ }^{130}$ the when's, where's, and how's of his subordinates' operations. $^{131}$

The head of the PNP in statute may be the Police General, but in the grander constitutional scheme of the Philippine Republic, he or she is but a puppet to the presidentpuppeteer. ${ }^{132}$ The "authority" of the former is in truth one of "agency" on behalf of the latter. ${ }^{133}$ Members of the PNP, from the Chief of Police to Patrolman, ${ }^{134}$ are but alter egos of the President. ${ }^{135}$ Duterte therefore unequivocally holds the material ability to control the PNP by either (i) directing the Police General, who would in turn exercise authority over the boots on the ground, or (ii) bypassing the Police General altogether and personally exercising control over PNP operations.

As evidenced by the episodic suspensions of the Oplan Tokhang, Duterte has exercised both direct and indirect control over the PNP. The anti-drug project was first suspended, upon Duterte's orders, on 30 January 2017 by then Chief of Police, Ronald "Bato" dela Rosa. ${ }^{136}$ The operation's cessation was made amidst the slaying of a South Korean national, Jee Ick-joo, inside Camp Crame - the headquarters of the PNP. ${ }^{137}$

Notably, the suspension was followed by a significant drop in reported police killings, ${ }^{138}$ albeit short-lived. On 6 March 2017, Duterte reinstituted a "more extensive, aggressive and well-coordinated" anti-illegal drug campaign, ${ }^{139}$ and with it, the extrajudicial killings. ${ }^{140}$

The Oplan Tokhang was again suspended following the highly controversial murder of Kian Loyd delos Santos. Kian was a senior high school student who, defenceless, pleading for his life, and without provocation, was shot by PNP officers at point blank range. ${ }^{141}$ Forensic examinations revealed that Kian sustained two gunshot wounds to the head. ${ }^{142}$ He was 17 -years-old. ${ }^{143}$

Public outcry ensued. On 10 October 2017, Duterte directly ordered the PNP to leave all anti-illegal drug operations to the PDEA (Philippine Drug Enforcement Agency). ${ }^{144}$ With

${ }^{130}$ Ibid., art. III; Executive Order No. 292, Book II, Chapter 1.

${ }^{131}$ National Electrification Administration v. Commission on Audit (G.R. No. 143481), [2002] 377 SCRA 223 at 239.

132 RA 6975, supra note 47, at section 14(o).

${ }^{133}$ Manalang-Demigillo v. TIDCORP (G.R. No. 168613), [2013] 692 SCRA 359 at 373.

${ }^{134}$ RA 6975, supra note 47, section 25. Cf. RA 11200, supra note 58, section 1.

135 Penafrancia v. Shipping Lines (G.R. No. 188952), [2016] 803 SCRA 679 at 704.

${ }^{136}$ Bea CUPIN, "Dela Rosa orders PNP: Stop war on drugs" Rappler (30 January 2017), online: Rappler <https:// www.rappler.com/nation/159931-pnp-dela-rosa-stop-drug-operations-focus-cleansing>.

${ }^{137}$ Marites VILLAMOR-ILANO, “Oplan Tokhang' suspension takes effect nationwide” SunStar Philippines (31 January 2017), online: SunStar Philippines <https://www.sunstar.com.ph/article/123445>.

${ }^{138}$ Camille DIOLA, "Vigilante Killings Disappear after Halt in Police Drug Efforts" Philippine Star (31 January 2018), online: Philippine Star <https://www.philstar.com/headlines/2017/01/31/1667271/vigilante-killings-disappear-after-halt-police-drug-efforts>.

${ }^{139}$ Philippine National Police, "PNP Activates Drug Enforcement Group: Double Barrel Reloaded, Tokhang Revisited” Philippine National Police (2017), online: Philippine National Police <http://www.pnp.gov.ph/newsand-information/773-pnp-activates-drug-enforcement-group-double-barrel-reloaded-tokhang-revisited>. $\quad C f$. Emmanuel TUPAS, “PNP ends Tokhang, Double Barrel” Philippine Star (12 October 2017), online: Philippine Star <https://www.philstar.com/headlines/2017/10/12/1748255/pnp-ends-tokhang-double-barrel>.

140 Jhoanna BALLARAN, “65 killed from December to February in PNP drug war relaunch" Philippine Daily Inquirer (15 February 2018), online: Philippine Daily Inquirer <https://newsinfo.inquirer.net/969100/65-killedfrom-december-to-february-in-pnp-drug-war-relaunch>.

${ }^{141}$ Oares, supra note 101 at 25.

142 Ibid., at 14.

143 Ibid.

144 Office of the President of the Philippines, "Memorandum from the President" Official Gazette (10 October 2017), online: Official Gazette <https://www.officialgazette.gov.ph/2017/10/10/memorandum-from-the-president-on-theimplementation-of-republic-act-9165-otherwise-known-as-the-comprehensive-dangerous-drugs-act-of-2002/>. See Ver MARCELO, "Duterte gives PDEA lead role in drug war" CNN Philippines (11 October 2017), online: CNN Philippines <http://nine.cnnphilippines.com/news/2017/10/11/president-rodrigo-duterte-pdea-lead-role-war-ondrugs.html>. 
the PDEA at the operational helm of the war on drugs, the number of reported extrajudicial killings plummeted to a single case. ${ }^{145}$ The Oplan Tokhang was resumed on 5 December $2017^{146}$ upon Duterte's orders in light of an alleged "resurgence in illegal drug activities and crimes" and public clamour. ${ }^{147}$ According to the PNP's own records, 53 drug personalities were killed in their operations in the following month and a half. ${ }^{148}$

Command responsibility is less concerned with the propinquity of a superior's authority $^{149}$ than with the practical capacity to control a subordinate's conduct. ${ }^{150}$ It is thus neither title nor position, but the fact of and failure to exercise effective control that triggers Article 28 liability. ${ }^{151}$ The suspensions of the Oplan Tokhang - an ebb and flow which caused a concomitant rise and fall in reported police killings ${ }^{152}$ - evidence how Duterte exercised that requisite level of control. In unambiguous terms, the President possesses the material capacity to curtail the spate of extrajudicial killings by his subordinates. He exercises both constitutional authority and effective control over the PNP.

\section{B. Mens Rea: "Knew" or "Should Have Known"}

Article 28(a) contains two mens rea standards. A military(-like) commander may only be held liable if he or she "knew" or "should have known" that his subordinates were committing, or about to commit, a criminal offense. The first of the two standards refers to the superior's actual knowledge of a subordinate officer's crimes, ${ }^{153}$ while the latter, "should have known", standard refers to a commander's duty "to take the necessary measures to secure knowledge of the conduct of his troops". ${ }^{154}$ Notably, "should have known" is more stringent than the ad hoc tribunals" "had reason to know" standard. ${ }^{155}$ It entails not only a reactive duty to act in light of information available, ${ }^{156}$ but a proactive duty to oversee and obtain knowledge of a subordinate's criminal conduct. ${ }^{157}$

\footnotetext{
${ }^{145}$ President of the Philippines, "Memorandum Order No. 17: Directing the Philippine National Police and Other Law Enforcement Agencies to Resume Providing Active Support to the Philippine Drug Enforcement Agency in the Conduct of Anti-Illegal Drug Operations" Office of the President (5 December 2017), online: Office of the President <https://lawphil.net/executive/mo/mo2017/pdf/mo_17_2017.pdf> at 1 [Memorandum Order No. 17].

${ }^{146}$ Ibid., at 2.

147 Ibid.

${ }^{148}$ Philippine National Police, "Real Numbers Statistics as of December 31, 2018” Philippine National Police (31 December 2018), online: Philippine National Police <http://www.pnp.gov.ph/images/News/2018/RealNumbers/ rn_123118.pdf> Cf. Presidential Communications Operations Office, "Real Numbers Press Briefing with Presidential Communications Operations Office Assistant Secretary Ana Marie Banaag, Philippine Drug Enforcement Agency (PDEA) Spokesperson Derrick Carreon, PNP Spokesperson Police Chief Supt. John Bulalacao, and PNP Directorate for Operations Acting Executive Officer PSSUPT. Rene Pamuspusan" Presidential Communications Operations Office (14 February 2018), online: Presidential Communications Operations Office $<$ https://pcoo.gov.ph/press-briefing/real-numbers-press-briefing-pcoo-assistant-secretary-ana-marie-banaag-philippine-drug-enforcement-agency-pdea-spokesperson-derrick-carreon-pnp-spokesperson-police-chief-supt-john-bulalacao/>.

${ }^{149}$ Prlić, supra note 119 at para. 238.

150 Bemba, supra note 11 at para. 417.

${ }^{151}$ The Prosecutor v. Jean-Pierre Bemba, Decision of 8 June 2018, Appeals Chamber, Case No. ICC-01/05-01/08 A, Wyngaert, J. and Morrison, J. separately concurring [Bemba Separate Opinion] at para. 33.

152 On causation, see Mettraux, supra note 16 at 87.

153 Prosecutor v. Charles Ghankay Taylor, Judgement of 18 May 2012, Trial Chamber II, Case No. SCSL-O3-01-T at para. 497.

${ }^{154}$ Bemba, supra note 11 at para. 433; Bemba Separate Opinion, supra note 151 at para. 37.

155 The Prosecutor v. Enver Hadžihasanović Amir Kubura, Judgement of 15 March 2003, Trial Chamber, Case No. IT-01-47-T [Hadžihasanović] at paras. 95-96.

${ }^{156}$ Karadžić, supra note 14 at para. 586.

${ }^{157}$ Bemba, supra note 11 at para. 433; Bemba Separate Opinion, supra note 151 at para. 37.
} 
Notwithstanding these distinctions, the availability of information that would give a commander "reason to know" of a subordinate's criminal conduct would naturally entail that he or she, likewise, "should have known". ${ }^{158}$ The ICC has thus relied on ICTY and ICTR-recognized indicia when determining whether the commander "should have known". ${ }^{159}$ These include the type and scope of the illegal acts, the modus operandi, their repetition, the officers involved, the implementation of reporting and monitoring systems, ${ }^{160}$ the crime's widespread nature, ${ }^{161}$ and its public manifestation. ${ }^{162}$

Either mens rea standard is satisfied in Duterte's war on drugs. Through Memorandum 17, Duterte expressly admits having actual knowledge of the "allegations [...] that summary killings of illegal drug suspects had been perpetrated by law enforcement agencies, particularly the PNP". ${ }^{163}$ What is more, Duterte has likewise extended executive clemency to all police officers implicated in the war on drugs ${ }^{164}$ - a power he holds under the 1987 Constitution. ${ }^{165}$ The pardon offer not only demonstrates Duterte's knowledge of his subordinates' conduct, but illustrates his grasp of the police killings' legal and criminal nature. ${ }^{166}$

The mental element is rarely manifested explicitly, ${ }^{167}$ yet Duterte is the exception to that rule. Through his own words, ${ }^{168}$ Duterte sets the stage for his own liability under command responsibility. But even if it were assumed that Duterte did not have "actual knowledge" of the police killings, certainly he "should have known" of them. The Oplan Tokhang is so widespread, public, and notorious ${ }^{169}$ it is impossible for the President to claim otherwise. ${ }^{170}$

\section{Actus Reus: The Failure to Exercise a Commander's Tripartite Duties}

Command responsibility encompasses three distinct duties: the duty to (i) prevent; (ii) repress; or (iii) report a subordinate's crimes. When there is a legal obligation to act, ${ }^{171}$ a commander is obliged to exercise these tripartite duties through necessary ${ }^{172}$ and

${ }^{158}$ See The Prosecutor v. Ignace Bagilshema, Judgement of 3 July 2002, Appeals Chamber, Case No. ICTR-95-1A-A at para. 28 .

${ }^{159}$ Bemba, supra note 11 at para. 434.

${ }^{160}$ Martinović, supra note 26 at para. 73.

${ }^{161}$ Prlić, supra note 119 at para. 247.

162 Ibid.

${ }^{163}$ Memorandum Order No. 17, supra note 145 at 2.

${ }^{164}$ Human Rights Watch, "World Report 2018, Philippines: Events of 2018” Human Rights Watch (2018), online: Human Rights Watch <https://www.hrw.org/world-report/2018/country-chapters/philippines>.

1651987 Constitution, supra note 88, art. VII, section 19.

${ }^{166}$ Bemba Separate Opinion, supra note 151 at para. 46.

${ }^{167}$ The Prosecutor v. Ndindiliyimana et al., Judgement and Sentence of 17 May 2011, Trial Chamber II, Case No. ICTR-00-56-T at para. 1198; Rivera v. People (G.R. No. 166326), [2006] 480 SCRA 188 at 196.

${ }^{168}$ See Memorandum Order No. 17, supra note 145; Felipe VILLAMOR, “Duterte Says, 'My Only Sin Is the Extrajudicial Killings"” The New York Times (27 September 2018), online: The New York Times <https://www. nytimes.com/2018/09/27/world/asia/rodrigo-duterte-philippines-drug-war.html>

${ }^{169}$ Human Rights Watch, supra note 112; Amnesty International, “If You are Poor You are Killed': Extrajudicial Executions in the Philippines' 'War on Drugs"' Amnesty International (27 January 2017), online: Amnesty International <https://www.amnestyusa.org/reports/if-you-are-poor-you-are-killed-extrajudicial-executions-inthe-philippines-war-on-drugs/>.

${ }^{170}$ The Prosecutor v. Édouard Karemera and Matthieu Ngirumpatse, Judgement and Sentence of 2 February 2012, Trial Chamber III, Case No. ICTR-98-44-T at para. 1530.

${ }^{171}$ Bemba, supra note 11 at para. 405.

172 Ibid., at para. 199. "Necessity" refers to the appropriateness of a measure. 
reasonable ${ }^{173}$ measures. The article will identify these respective elements within the Philippines' legal framework.

\section{Command Responsibility in Philippine Municipal Law}

The Philippines is no stranger to command responsibility. Historically, the doctrine was first applied to war crimes committed within its islands. ${ }^{174}$ Statutorily, it is replete in the Philippines' legal system. ${ }^{175}$

The Philippines adopted the doctrine of command responsibility as early as 1876 through the Old Penal Code (OPC), a "Filipinized" rendition of Spain's Codigo Penal, ${ }^{176}$ by holding rebel leaders liable for the individual felonies of their subordinates "in case the real perpetrators could not be found". ${ }^{177}$ Although the doctrine would be twice rejected from Philippine legal order thereafter (first, under American colonial rule with the OPC's repeal through the passage of the Revised Penal Code, ${ }^{178}$ and second, by the drafters of the 1987 Constitution $^{179}$ ), command responsibility presently finds itself in Philippine law through administrative,${ }^{180}$ fact-finding, ${ }^{181}$ and criminal law mechanisms. ${ }^{182}$

Most relevant to this study is RA 9851, which localizes ${ }^{183}$ the Rome Statute by adopting Article 5's core crimes ${ }^{184}$ and reflecting its modes of criminal liability. ${ }^{185}$ Section 10 enshrines the doctrine of command responsibility ${ }^{186}$ by imputing:

criminal liability to those superiors who, despite their position, still fail to take all necessary and reasonable measures within their power to prevent or repress the commission of illegal acts or to submit these matters to the competent authorities for investigation and prosecution. ${ }^{187}$

\footnotetext{
${ }^{173}$ Bemba Separate Opinion, supra note 151 at para. 170: “"[r] easonability' looks to the application of that measure within the operational realities on the ground at the time".

${ }^{174}$ Yamashita v. Styer, supra note 7.

175 See generally Raphael Lorenzo A. PANGALANGAN, "Crime and Omission: Command Responsibility from Manila to Rome" (2020) 1 Asia Pacific Journal of International Humanitarian Law 1 at 48-64.

${ }^{176}$ Jose A. JAVIER, “A Short Study of the Philippine Revised Penal Code” (1934) 14 Philippine Law Journal 161 at 161 .

${ }^{177}$ People v. Geronimo (G.R. No. L-8936), [1956] 100 SCRA 91 at 100.

${ }^{178}$ Vicente V. MENDOZA, “Criminal Law” (1957) 32 Philippine Law Journal 1at 13.

179 Joaquin G. BERNAS, “Command Responsibility” Philippine Center for Investigative Journalism (5 February 2007):
} "[i]t read thus: 'In the case of grave abuses committed against the right to life by members of the military or the police forces or their adversary, the presumption of command responsibility shall apply, and the state must compensate the victims of government forces.' But the proposal met with vigorous objections on the grounds of due process and the principle of nullum crimen sine lege."

${ }^{180}$ Executive Order No. 226, series of 1995, “Institutionalization of the Doctrine of 'Command Responsibility' in all Government Offices, Particularly at all Levels of Command in the Philippine National Police and Other Law Enforcement Agencies" (1995).

${ }^{181}$ Republic of the Philippines Supreme Court, “A.M. No. 07-9-12-SC. The Rule on the Writ of Amparo” (2007). Cf. Rodriguez v. Macapagal-Arroyo (G.R. No. 191805), [2011] 660 SCRA 84 at 128.

${ }^{182}$ Republic Act No. 9851, “An Act Defining and Penalizing Crimes Against International Humanitarian Law, Genocide and Other Crimes Against Humanity, Organizing Jurisdiction, Designating Special Courts, and for Related Purposes" (2009) [RA 9851]. See also Republic Act No. 10353, “An Act Defining and Penalizing Enforced or Involuntary Disappearance" (2012).

${ }^{183}$ The Rome Statute entered into force in the Philippines on 1 November 2011, two years after the effectivity of RA 9851.

${ }^{184}$ RA 9851, supra note 182, Chapter III. Cf. Bayan Muna v. Romulo (G.R. No. 159618), [2011] 641 SCRA 244 at 321 (Carpio J. dissenting).

${ }^{185}$ RA 9851, supra note 182, Chapter V.

${ }^{186}$ Ibid., section 10. RA 9851 imposes the "should have known" standard on all superiors.

${ }^{187}$ Boac, supra note 103 at 623. 
The take care clause obliges Duterte to ensure that his officers comply with the dictates of the law, ${ }^{188}$ but it is RA 9851 that particularizes that general obligation into the language of a commander's tripartite duties. By statutory fiat, the failure to execute that constitutional duty vis-à-vis a subordinate officer's offenses is made criminal under the doctrine of command responsibility.

\section{Necessary and Reasonable Measures}

Command responsibility does not insist on the impossible. As made clear by the acquittal of $\mathrm{Mr} \mathrm{Bemba}$, the doctrine of command responsibility only requires those measures that are "reasonable" and "necessary" to prevent, repress, or report a subordinate's offense; the standard of appropriateness being one of context. ${ }^{189}$ If the underlying crime is merely being attempted, the superior must order its cessation and adopt measures to ensure compliance therewith. ${ }^{190}$ But if the crime had already been consummated, it is his duty to secure its discontinuation ${ }^{191}$ and to express to the body of subordinate officers, through investigation, disciplinary sanction, or prosecutorial action ${ }^{192}$ that such conduct will not be countenanced. ${ }^{193}$ When the superior does not have the authority to directly punish his forces, then he or she must report the matter to the appropriate bodies that do. ${ }^{194}$

What is "reasonable" and "necessary" is ultimately a question of what is authorized and available given the circumstances. The threshold test is whether "a commander does what he or she can in the particular circumstances he or she faces in order to fulfil his or her duty to prevent, repress and punish the commission of crimes by those under his or her command."195

The limits to the President's power of control over the entirety of the executive branch being few and far between, and the Bemba Appeals Chamber having cautioned against hindsight evaluations, the measures available to Duterte are identified in concreto: ${ }^{196}$

Duty to Prevent: Suspending the Oplan Tokhang's operation to prevent further police killings ${ }^{197}$ - a power demonstrated through the sporadic and short-lived suspensions of the PNP's anti-drug enforcement plan. ${ }^{198}$

Duty to Repress: Ordering (i) the discontinuation of Oplan Tokhang; (ii) the investigation of crimes already committed - either internally ${ }^{199}$ by the PNP or by an external body such as the National Bureau of Investigation; ${ }^{200}$ and (iii) dismissing those responsible from the public service. ${ }^{201}$

\footnotetext{
188 Ople v. Torres (G.R. No. 127685), [1998] 293 SCRA 141 at 150; Ocampo v. Enriquez (G.R. No. 225973), [2016] 827 SCRA 224 at 269.

${ }^{189}$ Bemba Separate Opinion, supra note 151 at 33.

${ }^{190}$ Prosecutor v. Pavle Strugar, Judgement of 31 January 2005, Trial Chamber II, Case No. IT-01-42-T at para. 421;

Prosecutor v. Naser Orić, Judgement of 30 June 2006, Trial Chamber II, Case No. IT-03-68-T at para. 326.

191 Bemba, supra note 11 at para. 439.

192 The Prosecutor v. Alfred Musema, Judgement and Sentence of 27 January 2000, Trial Chamber I, Case No. ICTR-96-13-T at para. 145.

193 The Prosecutor v. Moinina Fofana, Allieu Kondewa (the CDF Accused), Judgement of 2 August 2007, Trial Chamber I, Case No. SCSL-04-14-T at para. 248.

${ }^{194}$ Bemba, supra note 11 at paras. 440-441.

${ }^{195}$ Martha M. BRADLEY and Aniel DE BEER, "All Necessary and Reasonable Measures - The Bemba Case and the Threshold for Command Responsibility” (2020) 20 International Criminal Law Review 2, 163-213, at 212.

${ }^{196}$ Bemba Appeals Judgement, supra note 151 at para. 167.

197 Saguisag v. Ochoa (G.R. No. 212426), [2016] 779 SCRA 241 at 339.

198 See Memorandum Order No. 17, supra note 145 at 1.

${ }^{199}$ Hadžihasanović, supra note 155 at para. 173. Cf. Republic Act No. 8551, "Philippine National Police Reform and Reorganization Act of 1998" (1998) section 39.

${ }^{200}$ Biraogo, supra note 125 at 216 (Carpio, J., dissenting).

${ }^{201}$ See for example CSC Resolution No. 1101502, "Revised Rules on Administrative Cases in the Civil Service" (2011) Rule 10. Executive Order 292, supra note 124 at Book V, Title I, Chapter VII.
} 
Duty to Report: Because the Constitution does not confer to the President the authority to directly impose penal sanctions for criminal conduct, Duterte should order the Department of Justice (DOJ) to prosecute those officers accused of extrajudicial killings before the courts of law. ${ }^{202}$

Duterte has fallen short of these tripartite duties. As of March 2018, the month Duterte unilaterally ordered the Philippines' withdrawal from the Rome Statute ${ }^{203}$ - there was no record of a single PNP official having been dismissed for conduct related to the Oplan Tokhang. ${ }^{204}$ The only exceptions came in November of that year through the prosecution of three police officers found criminally responsible for the murder of Kian Loyd delos Santos ${ }^{205}$ - the sole criminal conviction of PNP authorities in the drug war. All other implicated officers in the war on drugs had received minor disciplinary sanctions, ${ }^{206}$ or escaped justice altogether with an assurance of executive clemency. ${ }^{207}$ Worse, rather than being punished, others were promoted ${ }^{208}$ - a clear contravention of the duty to repress. ${ }^{209}$

Come September 2021, in the face of a looming ICC investigation, Duterte ordered the DOJ and PNP to conduct a probe into the anti-drug campaign. ${ }^{210}$ On 19 October 2021, the DOJ released a data matrix revealing that, of the alleged 30,000 dead, a mere 52 cases had been reviewed. ${ }^{211}$ As observed by the Center for International Law - Philippines (CENTERLAW), "the great majority of the 52 cases only resulted in administrative sanctions", with only seven resulting in the PNP officer's dismissal from the service, and a singular case being recommended for the filing of criminal charges. ${ }^{212}$

Though this may show that Duterte has, on some occasions and in some way, censured the civilian casualties in his drug war, absent any real action taken to address the ongoing massacre, Duterte merely pays lip service to the Filipino people. Yet, what is more, his passivity worsens the already harrowing state of human rights in the country. It creates

\footnotetext{
${ }^{202}$ Biraogo, supra note 125 at 336 (Leonardo-De Castro, J., separately concurring).

${ }^{203}$ See Press Release for Cayetano v. Pangilinan (G.R. No. 238875/G.R. No. 239483/G.R. No. 240954), 16 March 2021.

${ }^{204}$ Manuel MOGATO, "Philippine police say 400 officers dismissed under Duterte government" Reuters (2 March 2018), online: Reuters <https://www.reuters.com/article/us-philippines-police/philippine-police-say400-officers-dismissed-under-duterte-government-idUSKCN1GE17>.

${ }^{205}$ Oares, supra note 101 . The accused were found guilty of Murder under the Revised Penal Code and sentenced to reclusion perpetua (20-30 years) without eligibility of parole.

${ }^{206}$ Dahlia SIMANGAN, “Is the Philippine “War on drugs' an Act of Genocide?” (2018) 20 Journal of Genocide Research 68 at 85 . The most severe penalty imposed was a six-month administrative suspension.

${ }^{207}$ Christina MENDEZ, "Duterte to pardon cops in drug killings" Philippine Star (19 July 2016), online: Philippine Star <https://www.philstar.com/headlines/2016/07/19/1604381/duterte-pardon-cops-drug-killings>.

${ }^{208}$ Alexis ROMERO, "Duterte promotes Oplan Tokhang brains" Philippine Star (14 November 2018), online: Philippine Star <https://www.philstar.com/nation/2018/11/14/1868349/duterte-promotes-oplan-tokhang-brains>.

${ }^{209}$ The Prosecutor v. Bosco Ntaganda (Decision Pursuant to Article 61(7)(a) and (b)), Decision of 9 June 2014, Pre-Trail Chamber II, Case No. ICC-01/04-02/06 at para. 173.

${ }^{210}$ Christia Marie RAMOS, "Duterte orders review of conduct of war on drugs" Philippine Daily Inquirer (22 September 2021), online: Philippine Daily Inquirer <https://globalnation.inquirer.net/199144/duterte-ordersreview-of-conduct-of-war-on-drugs>.

${ }^{211}$ Department of Justice, "Information Table on the Fifty-Two (52) Cases Submitted by the PNP and PNP-IAS to the Department of Justice" (19 October 2021).

${ }^{212}$ Center for International Law Philippines, "Sound and Fury Signifying Nothing: A CENTERLAw Statement on the DOJ Review of 52 Cases in the war on drugs" (20 October 2021). See Lian BUAN, "Lawyers who probed drug war say DOJ matrix not good enough" Rappler (20 October 2021), online: Rappler <https://www.rappler. $\mathrm{com} /$ nation/nupl-flag-centerlaw-ideals-statement-doj-drug-war-matrix>.
} 
an atmosphere of impunity where subordinate officers are led to believe that their illegal conduct is acceptable and will go unpunished. ${ }^{213}$

Duterte has failed to take necessary and reasonable measures available to him as Philippine President. ${ }^{214}$ Contrary to Duterte's defence, his passivity is not exculpatory. Quite the opposite: it sets the stage for command responsibility.

\section{What's in a Name? Omissions and Fair Labels}

The architects of mass atrocities might not "soil their own hands with blood", ${ }^{215}$ yet may still incur criminal liability in various ways. Each mode of individual liability comes with its respective criteria; some more difficult to establish than others. At the outset, the article dispenses with indirect "perpetratorship" under Articles 25(3)(a) and (b), absent a showing that Duterte had ordered, solicited, induced, or otherwise exercised control over specific extrajudicial killings. ${ }^{216}$ Indeed, the issue at hand is not criminal commission, but presidential omission.

For this same reason, neither will Article 25(3)(d) find application. Structurally similar to the Joint Criminal Enterprise (JCE) liability adopted by the ad hoc tribunals, Article 25 (3)(d) emphasizes group criminality. ${ }^{217}$ Unlike the JCE system, however, which embraces "an act or omission that makes an enterprise efficient or effective", ${ }^{218}$ subparagraph (d) requires a significant contribution to the crime. That is, actions that are performed in accordance with a common plan. ${ }^{219}$

Even if Article 25(3)(d) were re-interpreted expansively to embrace both action and inaction, neither would it merit much discussion for Duterte in the Situation in the Philippines. As will be shown, there is something amiss about imputing to the President of the nation the "least grave" mode of participation that involves the the "lowest degree of responsibility". ${ }^{20}$ Thus, this part will compare and contrast Duterte's omission liability under Articles 25(3)(c), 28(a), and 28(b) of the Rome Statute.

\section{A. Alternative Modes of Criminal Responsibility}

\section{Article 25(3)(c): Aiding and abetting}

Aiding and abetting is a form of accessory liability ${ }^{221}$ for individuals who, "[f]or the purpose of facilitating the commission of [...] crime, aids, abets or otherwise assists in its commission or its attempted commission". 22 "Aiding" refers to the rendering of practical assistance, ${ }^{223}$

\footnotetext{
${ }^{213}$ The Prosecutor v. Ignace Bagilishema, Judgement of 7 June 2001, Trial Chamber I, Case No. ICTR-95-1A-T at para. 50.

${ }^{214}$ Hadžihasanović, supra note 155 at para. 1461.

${ }^{215}$ Jackson, supra note 1.

${ }^{216}$ Rome Statute, supra note 3, art. 25(3)(a) and 25(3)(b). Cf. Human Rights Watch, supra note 112 at 17.

217 The Prosecutor v. Callixte Mbarushimana, Judgment of 16 December 2011, Pre-Trial Chamber I, Case No. ICC-01/04-01/10 at para. 282 [Mbarushimana].

${ }^{218}$ Prosecutor v. Miroslav Kvočka, Judgement of 2 November 2001, Trial Chamber, Case No. IT-98-30/1-T at para. 309. See Randle C. DEFALCO, "Contextualizing Actus Reus under Article 25(3)(d) of the ICC Statute: Thresholds of Contribution" (2013) 11 Journal of International Criminal Justice 715 at 720.

${ }^{219}$ Mbarushimana, supra note 217 at para. 282.

${ }^{220}$ See Kai AMBOS, “Article 25: Individual Criminal Responsibility” in Otto TRIFFTERER and Kai AMBOS, eds., Commentary on the Rome Statute of the International Criminal Court (England: Hart 2016) at 1011.

${ }^{221}$ The Prosecutor v. Paul Bisengimana, Judgement and Sentence of 13 April 2006, Trial Chamber II, Case No. ICTR-00-60-0078/1 at para. 33.

${ }^{222}$ Rome Statute, supra note 3, art. 28(3)(a).

${ }^{223}$ The Prosecutor v. Elizaphan and Gérard Ntakirutimana, Judgement of 13 December 2004, Appeals Chamber, Case No. ICTR-96-17 at para. 787.
} 
while "abetting" means encouraging, advising, or instigating the commission of a crime. ${ }^{224}$ While coined conjunctively (i.e. aiding and abetting), jurisprudence has treated these terms disjunctively. ${ }^{225}$ Proof of either would suffice to establish the "broad singular legal concept" ${ }^{26}$ echoed through Article 25(3)(c)'s catchall expression: to "otherwise assist". 27

Aiding and abetting may be nuanced in temporis, loci, and materiae. It encompasses assistance before, during, or after the crime had been perpetrated, ${ }^{228}$ whether rendered at the scene of the crime or removed therefrom. ${ }^{229}$ In terms of materiae, it comes in many forms: by word or by deed, ${ }^{230}$ through action or omission. ${ }^{231}$ The assistance need not be tangible, ${ }^{232}$ as in merely lending encouragement or moral support, ${ }^{233}$ or purposely failing to act when there is a legal duty and capacity to do so, ${ }^{234}$ may constitute aiding and abetting.

So long as the act or absence thereof is made to advance the perpetration of a specific crime ${ }^{235}$ it falls within the purview of Article $25(3)(c) .{ }^{236}$ It is a form of accessorial liability precisely because the accused merely contributes to a crime committed by another. ${ }^{237}$ It is the "weakest form of complicity" 238 and generally warrants a lesser sentence than other modes of participation. ${ }^{239}$

\section{Article 28(b): Superior responsibility}

Article $28(b)$ is found within the negative spaces of its military(-like) counterpart. It applies only "to superior and subordinate relationships not described in paragraph (a)", ${ }^{240}$ though it subscribes to the same (i) effective control; (ii) actus reus (i.e. the failure to take reasonable and measures to prevent, repress, or report subordinate offenses); and (iii) mens rea framework. Civilian superior responsibility, however, deviates from Article 28(a) through a less stringent mental element ${ }^{241}$ and a more nuanced scope of responsibility. ${ }^{242}$

\footnotetext{
${ }^{224}$ Prosecutor v. Milorad Krnojelac, Judgement of 15 March 2002, Trial Chamber, Case No. IT-97-25 at para. 89.

${ }^{225}$ Prosecutor v. Limaj et al., Judgement of 30 November 2005, Trial Chamber II, Case No. IT-03-66 at para. 516.

${ }^{226}$ Bisengimana, supra note 221 at para. 32 .

${ }^{227}$ Rome Statute, supra note 3, art. 25(3)(c). Cf. Ambos, supra note 220 at 1006. See also Semanza, supra note 116 at paras. 384-385; Prosecutor v. Halilović, Judgement of 16 November 2005, Trial Chamber I, Case No. IT-01-48-T at para. 95 [Halilović].

${ }^{228}$ Prosecutor v. Radislav Krstić, Judgement of 2 August 2001, Trial Chamber, Case No. IT-98-33, at para. 601.

229 Ibid.

${ }^{230}$ Semanza, supra note 116 at paras. 384-385.

${ }^{231}$ Prosecutor v. Radoslav Brdjanin, Judgement of 1 September 2004, Trial Chamber, Case No. IT-99-36 at para.

271 [Brdjanin]; Karadžić, supra note 14 at para. 575; Prosecutor v. Augustin Ngirabatware, Appeal Judgement of 18 December 2014, Appeals Chamber, Case No. MICT-12-29-A at para. 150.

${ }^{232}$ Prosecutor v. Šainović et al., Appeal Judgement of 23 January 2014, Appeals Chamber, Case No. IT-05-87-A at para. 1629.

${ }^{233}$ Brdjanin, supra note 231 at para. 271; Prosecutor v. Anto Furundžija, Judgement of 10 December 1998, Trial Chamber, Case No. IT-95-17/1-T at para. 232.

${ }^{234}$ The Prosecutor v. Pauline Nyiramasuhuko et al., Appeal Judgement of 14 December 2015, Appeals Chamber, Case No. ICTR-98-42-A at para. 2189.

${ }^{235}$ Karadžić, supra note 14 at para. 575.

${ }^{236}$ Prosecutor v. Vojislav Šešelj, Judgement of 31 March 2016, Trial Chamber, Case No. IT-03-67-T, at para. 353.

${ }^{237}$ Karadžić, supra note 14 at para. 574.

${ }^{238}$ Ambos, supra note 220 at paras. 1003-4. See Prosecutor v. Tadić, IT-94-1-A (15 July 1995) 192.

239 Prosecutor v. Vasiljević, Appeal Judgement of 25 February 2004, Appeal Chamber, Case No. IT-98-32 at para. 182; Prosecutor v. Mrkšić et al., Appeal Judgement of 5 May 2009, Appeals Chamber, Case No. IT-95-13/1 at para. 407.

${ }^{240}$ Rome Statute, supra note 3, art. 28(b). Cf. The Prosecutor v. Laurent Gbagbo, Decision on the Confirmation of Charges of 12 June 2014, Pre-Trial Chamber I, Case No. ICC-02/11-01/11 at para. 26 [Gbagbo].

${ }^{241}$ Ibid., art. 28(b)(i).

${ }^{242}$ Ibid., art. 28(b)(ii).
} 
In terms of the mental element, Article 28(b) similarly contains two mens rea standards: (i) actual knowledge and (ii) imputed knowledge. Like Article 28 (a), the civilian leader has "actual knowledge" when he or she is aware of the crimes that have been or are about to be committed. ${ }^{243}$ However, short of actual knowledge, superiors may only be held liable if they "consciously disregard" information which clearly indicate the subordinates' criminal conduct. ${ }^{244}$ In contrast to Article 28(a)'s "should have known" standard, there is no "active duty" for the civilian leader to obtain information about a subordinate's conduct, ${ }^{245}$ but only a "lessened duty" ${ }^{246}$ not to ignore it. ${ }^{247}$ Short of actual knowledge, civilian superiors may, therefore, only be held liable under the doctrine of willful blindness - i.e. the deliberate avoidance of readily available information. ${ }^{248}$

Article 28(b) likewise deviates from Article 28(a) by expressly limiting a civilian leader's liability to "crimes concern[ing] activities that were within the effective responsibility and control" of the superior. ${ }^{249}$ Civilian superiors are, therefore, only responsible for crimes committed by a subordinate acting in their official function, ${ }^{250}$ i.e. "acts only at work and not for acts they committed outside the workplace in their individual capacity". 251

The travaux preparatoires of the Rome Statute reveal that these more lenient standards were purposely adopted to correspond to the less stringent disciplinary structures in civilian life. ${ }^{252}$ Article 28 (b) has thus been described as a "weaker" form of liability for failing to deter civilian superiors to the same extent as military(-like) commanders. ${ }^{253}$

\section{B. Fairly Labelling the Truth in the Trenches}

A glaring difference between command responsibility on one hand, and aiding and abetting and superior responsibility on the other, is military-likeness - a hurdle for Article 28 (a) alone. The previous two parts having already established Duterte's liability as a military-like commander, the obvious question arises: why reach for high-hanging fruit?

This part addresses the query through fair labelling: the principle of law that aims to ensure that legal "labels" ascribed to criminality "accurately reflects both its wrongfulness and its severity". ${ }^{254}$ Fair labelling bridges truth with justice by pursuing justice through truth, whether with regard to the crime per se or the role of criminal participation. ${ }^{255}$

Duterte's failure to control the PNP may constitute either aiding and abetting under Article 25 or trigger command responsibility under Article 28. A thin but dividing line may be drawn between these modes of participation in terms of both the criminal mind (mens rea) and the criminal act or omission (actus reus). While an aider and abettor must intend to assist the crime; mere awareness would suffice for command

\footnotetext{
${ }^{243}$ Taylor, supra note 153 at para. 497.

${ }^{244}$ Rome Statute, supra note 3, art. 28(b)(i).

${ }^{245}$ Bemba, supra note 11 at para. 433.

${ }^{246}$ Vetter, supra note 4 at 123.

${ }^{247}$ Taylor, supra note 153 at paras. 498-499.

${ }^{248}$ Triffterer, supra note 119 at 1124.

${ }^{249}$ Rome Statute, supra note 3, art. 28(a).

${ }^{250}$ Ibid., art. 28(b). Cf. Triffterer, supra note 119 at 1103.

${ }^{251}$ Summary Record, supra note 21 at 67-68.

252 Bemba, supra note 11 at para. 433. See Gonzales v. Abaya (G.R. No. 164007), [2006] 498 SCRA 445, para. 474.

${ }^{253}$ Vetter, supra note 4 at 94.

${ }^{254}$ David NERESSIAN, "Comparative Approaches to Punishing Hate: The Intersection of Genocide and Crimes against Humanity" (2007) 43 Stanford Journal of International Law 221 at 255.

${ }^{255}$ The Prosecutor v. Mathieu Ngudjolo Chui, Judgment pursuant to Article 74 of the Statute, Decision of 18 December 2012, Trial Chamber II, Case No. ICC-01/04-02/12 at para. 28 (Wynegart, J., concurring).
} 
responsibility. ${ }^{256}$ On the other hand, while the overt act of omission may fall within the ambit of either Article 25(3)(c) or Article 28, the accused's responsibility is more aptly described as a mode of direct participation when the omission is a "component of the deliberate effort to achieve" the crime. ${ }^{257}$ The distinction between the omissive conduct of refusing to act (i.e. Article 25) and failing to act (i.e. Article 28) is, thus, a question of deliberateness. ${ }^{258}$

Admittedly, a strong case exists for prosecuting Duterte's omissions under Article 25(3) (c). His failure to enforce his tripartite duties over the PNP sends the message that "those involved [in the Oplan Tokhang killings] need not fear being held to account, and future killings can be carried out with impunity." ${ }^{259}$ When taken in light of the influence he derives from his stature, ${ }^{260}$ Duterte's passivity, deliberate and purposeful, encourages the proliferation of police killings, thus rendering him as an aider and abettor.

However, therein lies the weakness of the mode of participation: Article 25(3)(c) understates Duterte's degree of criminal responsibility. ${ }^{261}$ Aiding and abetting depicts the President - the single most powerful person under the Philippine Constitution - as an accessory to the PNP. But as already illustrated, it is Duterte who controls the police, not viceversa. Characterizing the President as the PNP's accessory not only minimizes Duterte's role in the war on drugs, but does so by turning Philippine legal order on its head.

The Oplan Tokhang is tightly entwined with Dutertian leadership. While the record might fail to prove that Duterte ordered mass killings, ${ }^{262}$ it would be the height of inaccuracy to characterize him as a mere accessory to them. Indeed, CMC 16-2016 expressly builds off Duterte's campaign promise "to get rid of illegal drugs during the first six months of his term" ${ }^{263}$ Duterte cannot, therefore, be tried as a mere incident to the war on drugs. On the contrary, he is its author.

A similar critique may be made for superior responsibility. From the outset, prosecuting Duterte as a civilian authority is a futile effort considering how Article 28(b) limits a superior's scope of responsibility to those crimes committed by a subordinate "while engaged in work-related activities". ${ }^{264}$ This standard is troublesome amid Philippine case law that excludes "criminal conduct" en masse from the scope of "official acts". ${ }^{265}$ Arguably, the jurisprudentially-created paradox carves out an across-the-board immunity from liability under Article 28(b). Civilian leaders can never be punished for failing to prevent, repress, or report crimes made within their effective responsibility and control because all crimes are deemed "ultra vires and cannot be part of official functions" 266 ab initio.

But beyond pragmatics is the principle. Like Article 25(3)(c), Article 28(b) simply fails to reflect the facts on the ground. As earlier established, Article 28 is less concerned with legal abstractions and bifurcates the rules of command responsibility precisely to

\footnotetext{
${ }^{256}$ Alexandre Skander GALAND, "Bemba and the Individualisation of War: Reconciling Command Responsibility under Article 28 Rome Statute with Individual Criminal Responsibility" 20 International Criminal Review 669, 697 citing Mbarushimana at para. 27; Rome Statute, supra note 3, art. 25(3)(c).

${ }^{257}$ Gbagbo, supra note 240 at paras. 264-265. See also Halilović, supra note 227 at para. 78.

${ }^{258}$ See Triffterer, supra note 119 at 1096.

${ }^{259}$ Human Rights Watch, supra note 112 at 15.

${ }^{260}$ The Prosecutor v. Aloys Simba, Judgement and Sentence of 13 December 2005, Trial Chamber I, Case No. ICTR-01-76-T at para. 439.

${ }^{261}$ Guilfoyle, supra note 50 at 268. Cf. Prosecutor v. Milutinović et al., Decision on Challenge to Jurisdiction of 22 March 2006, Trial Chamber III, Case No. IT-05-87-PT at para. 2.

${ }^{262}$ Human Rights Watch, supra note 112 at 17.

${ }^{263}$ CMC 16-2016, supra note 36 at 1(a).

${ }^{264}$ Ronen, supra note 67 at 341.

${ }^{265}$ Liang v. People (G.R. No. 125865), [2000], 393 SCRA 692 at 696; Liang v. People (G.R. No. 125865), [2001] 355 SCRA 125 at 156.

${ }^{266}$ Ibid.
} 
recognize the real distinctions between civilian and military relations. ${ }^{267}$ Yet charging Duterte as a civilian leader in light of the PNP's civilian mandate contradicts that underlying purpose. It would be to insist on black letter law definitions of police work and ignore the sombre reality that civilian forces do at times wield militaristic force.

Charging Duterte as a non-military superior simply fails to capture these truths, and the truth is no abstract consideration. ${ }^{268}$ Not all crimes are the same. Neither are all modes of criminal participation made equal. Indeed, the history of international criminal law shows that gradations of criminality exist even in grand atrocities, may they be executed by foot soldiers or commanders, accessories or principals. Courts of law are, after all, not solely engaged in legal determinations but in truth-telling. ${ }^{269}$ There is therefore a need to bridge factual finding with the appropriate legal characterization. ${ }^{270}$ The law's didacticism demands no less.

Fair labelling tells the story of criminality. ${ }^{271}$ In the grander scheme of things, judgemade ascertainment is not only jurisprudential but declaratory. ${ }^{272}$ It projects to the partylitigants and the public writ large the "wrongfulness of the act and the blameworthiness of the offender". ${ }^{273}$ The ultimate goal of any judicial proceeding is not solely to adjudge liability, but to identify guilt in a manner that demarcates "widely felt distinctions between kinds of offences and degrees of wrongdoing." 274 To do away with these fine distinctions would be to muddle the levels of brutality, the felt pains they have caused, and the degrees of responsibility therefore. The challenge to the courts is to draw out these nuances through their decisions. The ICC is not exempt from that challenge. ${ }^{275}$ On the contrary, it has in fact acknowledged its own authority to modify legal characterizations of facts so that they conform with the established crime/s and evidenced mode/s of liability. ${ }^{276}$

Charging Duterte under command responsibility does not by any means escape criticism. In contrast to direct perpetration under Article 25, Article 28 is likewise faulted for trivializing the responsibility of criminal architects as mere bus drivers "asleep at the wheel [rather than] driving purposively toward disaster". ${ }^{277}$ The analogy is not

\footnotetext{
${ }^{267}$ Summary Record, supra note 21 at 67.

${ }^{268}$ See The Basic Principles and Guidelines on the Right to a Remedy and Reparation for Victims of Gross Violations of International Human Rights Law and Serious Violations of International Humanitarian Law, GA Res. 60/147, UN Doc. A/ RES/60/147 (21 March 2006); UN Set of Principles for the Protection and Promotion of Human Rights through Action to Combat Impunity, UNHRC Committee Res. 102/Add.1, UN Doc. E/CN.4/2005/102/Add.1 (8 February 2005).

${ }^{269}$ Elinor FRY, "The Nature of International Crimes and Evidentiary Challenges: Preserving Quality While Managing Quantity” in Elies VAN SLIEDREGT and Sergey VASILIEV, eds., Pluralism in International Criminal Law (Oxford: Oxford University Press 2014) at 258.

${ }^{270}$ Brianne LEYH, "Pragmatism Over Principles: The International Criminal Court and a Human Rights-Based Approach to Judicial Interpretation” (2018) 41(3) Fordham International Law Journal 697 at 704.

${ }^{271}$ Talita DE SOUZA DIAS, "Recharacterisation of Crimes and the Principle of Fair Labelling in International Criminal Law” (2018) 18 International Criminal Law Review 788 at 795.

${ }^{272}$ Rome Statute, supra note 3, art. 21(2). Cf. Hilmi ZAWATI, Fair Labelling and the Dilemma of Prosecuting Gender-Based Crimes at the International Criminal Tribunals (Oxford: Oxford University Press 2014) at 32.

${ }^{273}$ Ibid., art. 21(2). Cf. James CHALMERS and Fiona LEVERICK, "Fair Labelling in Criminal Law" (2008) 71 The Modern Law Review 217 at 227.

${ }^{274}$ See Andrew ASHWORTH, Principles of Criminal Law (Oxford: Oxford University Press 2006) at 88.

${ }^{275}$ Rome Statute, supra note 3, art. 21(2)(b); United Nations, Statute of the International Court of Justice (18 April 1946), art. 38. Cf. Victor TADROS, "Fair Labelling and Social Solidarity" in Lucia ZEDNER and Julian ROBERTS, eds., Principles and Values in Criminal Law and Criminal Justice: Essays in Honour of Andrew Ashworth (Oxford: Oxford University Press 2012) at 68.

${ }^{276}$ Regulation of the Court: Official documents of the International Criminal Court, ICC-BD/01-02-07, International Criminal Court (18 December 2007), Regulation 55 at 1.

${ }^{277}$ Lachezar YANEV, Theories of Co-perpetration in International Criminal Law (Leiden: Brill 2018) at 2, citing Mark OSIEL, Making Sense of Mass Atrocity (Cambridge: Cambridge University Press 2011) at 56.
} 
without merit. But when taken in light of the situation at hand, where there is "no evidence [that] shows that Duterte planned or ordered specific extrajudicial killings", ${ }^{278}$ it is simply inapplicable. To insist on Article 25(3)(c) solely to illustrate direct participation would not portray Duterte as the "driver behind the wheel", but a bus aide on another's ride.

Article 25(3)(c) understates Duterte's role in the Oplan Tokhang by portraying him as an accessory to the PNP - an inaccurate description of a President's authority under the Philippines' doctrinal and factual contexts. On the other hand, Article 28 rightfully captures the responsibility of those who command others - "a form of liability for those who by training, arming, or deploying dangerous forces [...] 'afforded, or participated in affording, the opportunity for the crime to be committed'." ${ }^{279}$ Article 28(b), however, ignores the fact that the PNP's civilian disposition has been distorted by Dutertian rule. Duterte should therefore be charged under Article 28(a), not solely because it is applicable, but because it is appropriate. It highlights the most peculiar characteristics of the drug war: Duterte's authoritarian role and the betrayal of a civilian mandate.

While command responsibility has been at times relegated as a subsidiary mode of liability vis-à-vis direct modes of participation, ${ }^{280}$ there is neither a statutory nor practical basis to prima facie prefer Article 25(3)(c) over Article $28 .{ }^{281}$ On the contrary, the status of fair labelling as a general principle of law $^{282}$ requires that Duterte be charged not only forcefully, but with precision. ${ }^{283}$ Article 28 (a) captures the truth in the trenches in ways that Articles 25(3)(c) and 28(b) simply do not, and the truth, at the very least, is this: as Chief Executive, Duterte has failed to carry-out his tripartite duties over a military-like force, the Philippine National Police.

\section{Conclusion}

The crimes in the Situation in the Philippines may be dubbed a "war", but it is neither an intense nor organized armed conflict. ${ }^{284}$ Indeed, what separates Duterte's war on drugs from the universe of command responsibility case law is how it is far-removed from the theatre of war. There are no two belligerents, but a sole player: the State. There is no "opposing force", only victims. The anti-drug campaign is no "war". It is a massacre.

Yet, neither is the war on drugs of a quintessential civilian nature. Part I of the article establishes how the PNP, by adopting the military-mind, constitutes a military-like force. RA 6975 may have given the PNP civilian character, yet the violence of the Oplan Tokhang betrays that legal fiction and undoes the statutory severance of the police from the constabulary that preceded it. By adopting the military-mind, the PNP has foregone the rules of civilian life and, in so doing, dons a military-likeness. As its Chief Executive, Duterte is a

\footnotetext{
${ }^{278}$ Human Rights Watch, supra note 112 at 17.

${ }^{279}$ Galand, supra note 256 at 697-698 citing Bemba Appeals Judgement 185 at para. 251 (Eboe-Osuji, concurring Opinion).

${ }^{280}$ See for example Prosecutor $v$ Thomas Lubanga Dyilo, Decision on the Confirmation of Charges, Decision of 29 January 2007, Pre-Trial Chamber I, Case No. ICC-01/04-01/06 at para. 321; Krstić, supra note 228 at para. 605; Prosecutor v. Milomir Stakić, Judgement of 31 July 2003, Trial Chamber, Case No. IT-97-24-T at para. 463.

${ }^{281}$ See Horejah BALA-GAYE, "Lexisitus Lecture: ICC Statute Article 28(a)" Center for International Law Research Policy (27 March 2017) 3, online: Center for International Law Research Policy <http://www.cilrap.org/cilrapfilm/28-a-balagaye/>.

${ }^{282}$ Tadros, supra note 275 at 68.

${ }^{283}$ Rome Statute, supra note 3, art. 21(1)(b): "The Court shall apply [...] the principles and rules of international law".

${ }^{284}$ Gideon LASCO, “Don't Call Philippines' Duterte's Anti-Drug Campaign a 'War on drugs”' The Globe Post (11 December 2018), online: The Globe Post <https://theglobepost.com/2018/12/11/philippines-duterte-drug-war/>.
} 
military-like commander under Article 28(a). To insist on subparagraph (b) would be to rely solely on black letter law, ignore the reality that even civilians command military-grade power, and turn a blind eye to the complex truth that police and military domains are distinguished by neither guns nor titles, but dispositions.

Through Part II, the article establishes the effective control, actus reus, and mens rea elements of command responsibility in the war on drugs. As amply illustrated by the sporadic suspensions of the Oplan Tokhang, Duterte not only has actual knowledge of the police killings, but the material ability to repress its continuation. Yet he has failed to do so. On both occasions of its suspension, the Oplan Tokhang was reinstituted in only a matter of weeks without any real changes in the PNP's policy or practice. Indeed, as openly admitted by the PNP, the death toll in their anti-drug operations continues to climb.

Part III demonstrates how Article 28(a) is not only applicable, but appropriate for the war on drugs. While aiding and abetting (Article 25(3)(c)) and superior responsibility (Article 28(b)) may likewise find application to Duterte's failure to prevent, repress, or punish the crimes committed in his drug war, they fail to reflect the essence and extent of Duterte's liability. On one hand, charging Duterte as an aider and abettor understates his role as a leader, let alone, as the Philippine President. On the other hand, in addition to the practical obstacles posed to Article 28(b) (i.e. the superior's limited scope of responsibility), charging Duterte as a civilian superior ignores the violence done to the PNP's civilian mandate. Article 28(a) captures the truth in the trenches by emphasizing how Dutertian rule distorts the civilian police function with military-like bellicose.

The problem with prosecuting Duterte as a military-like commander is the tendency to view the PNP as a civilian agency simply because the law characterizes it as such. But as already established, Article 28 is the turning of the tide from binary to reality. It is concerned less with legal characterizations than with the facts on the ground, and departs from the civilian-military dichotomy to accommodate the phenomenon of civilian leaders who wield military-like power. Duterte falls squarely within this category and, absent evidence of an active role in the drug war, should be sanctioned as a military-like commander.

Duterte's war on drugs fulfils the elements of command responsibility but, more importantly, command responsibility captures the truth of the war on drugs. It would thus not suffice to simply bring those responsible to the courts of law. We must likewise speak truth to justice. While charging Duterte under alternative modes of liability may undoubtedly satisfy "the high feelings of the moment", truth should not be compromised for justice, lest we ignore Yamashita's ghost, hold Duterte liable as something he is not, and leave to "the sober afterglow" of this difficult choice "the realization of [its] boundless and dangerous implications". ${ }^{285}$

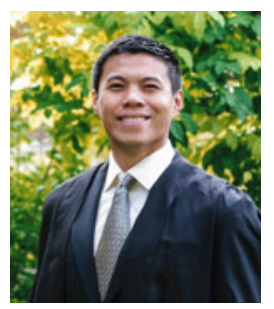

Raphael Lorenzo A. PANGALANGAN completed his law studies at the University of Philippines, the University of Oxford, and the University of Cambridge. He currently is an assistant professor with Jindal Global Law School and is a visiting scholar at Harvard Law School. He likewise represents victims of the Philippine "drug war" as a Fellow at the Center for International Law - Philippines.

${ }^{285}$ In re Yamashita, supra note 6 at para. 37 (Murphy, J., dissenting).

Cite this article: PANGALANGAN RLA (2022). Command Responsibility in the Times of Tokhang: Defining Military-likeness under Article 28(a) of the Rome Statute. Asian Journal of International Law 12, $267-291$. https://doi.org/10.1017/S2044251321000618 